\title{
PAST, PRESENT, AND FUTURE OF IRRIGATION ON THE U.S. GREAT PLAINS
}

\author{
S. R. Evett, P. D. Colaizzi, F. R. Lamm, S. A. O’Shaughnessy, \\ D. M. Heeren, T. J. Trout, W. L. Kranz, X. Lin
}

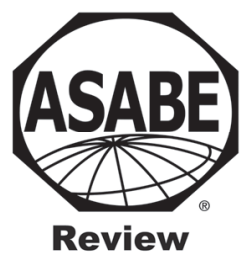

\section{HighLIGHTS}

- Irrigation is key to the productivity of Great Plains agriculture but is threatened by water scarcity.

- The irrigated area grew to $>9$ million ha since 1870 , mostly since 1950 , but is likely to decline.

- Changes in climate, water availability, irrigated area, and policy will affect productivity.

- Adaptation and innovation, hallmarks of Great Plains populations, will ensure future success.

ABSTRACT. Motivated by the need for sustainable water management and technology for next-generation crop production, the future of irrigation on the U.S. Great Plains was examined through the lenses of past changes in water supply, historical changes in irrigated area, and innovations in irrigation technology, management, and agronomy. We analyzed the history of irrigated agriculture through the 1900s to the present day. We focused particularly on the efficiency and water productivity of irrigation systems (application efficiency, crop water productivity, and irrigation water use productivity) as a connection between water resource management and agricultural production. Technology innovations have greatly increased the efficiency of water application, the productivity of water use, and the agricultural productivity of the Great Plains. We also examined the changes in water stored in the High Plains aquifer, which is the region's principle supply for irrigation water. Relative to other states, the aquifer has been less impacted in Nebraska, despite large increases in irrigated area. Greatly increased irrigation efficiency has played a role in this, but so have regulations and the recharge to the aquifer from the Nebraska Sand Hills and from rivers crossing the state. The outlook for irrigation is less positive in western Kansas, eastern Colorado, and the Oklahoma and Texas Panhandles. The aquifer in these regions is recharged at rates much less than current pumping, and the aquifer is declining as a result. Improvements in irrigation technology and management plus changes in crops grown have made irrigation ever more efficient and allowed irrigation to continue. There is good reason to expect that future research and development efforts by federal and state researchers, extension specialists, and industry, often in concert, will continue to improve the efficiency and productivity of irrigated agriculture. Public policy changes will also play a role in regulating consumption and motivating on-farm efficiency improvements. Water supplies, while finite, will be stretched much further than projected by some who look only at past rates of consumption. Thus, irrigation will continue to be important economically for an extended period. Sustaining irrigation is crucial to sustained productivity of the Great Plains "bread basket" because on average irrigation doubles the efficiency with which water is turned into crop yields compared with what can be attained in this region with precipitation alone. Lessons learned from the Great Plains are relevant to irrigation in semi-arid and subhumid areas worldwide.

Keywords. Center pivot, Crop water productivity, History, Sprinkler irrigation, Subsurface drip irrigation, Water use efficiency.

ttps://creative commons.org/licenses/by-nc-nd/4.0/

Submitted for review in August 2019 as manuscript number NRES 13620; approved for publication as an Invited Review by the Natural Resources \& Environmental Systems Community of ASABE in January 2020.

Mention of company or trade names is for description only and does not imply endorsement by the USDA. The USDA is an equal opportunity provider and employer.

The authors are Steven R. Evett, Research Soil Scientist, and Paul D. Colaizzi, Research Agricultural Engineer, USDA-ARS Conservation and Production Research Laboratory, Bushland, Texas; Freddie R. Lamm, Research Agricultural Engineer, Northwest Research-Extension Center, Kansas State University, Colby, Kansas; Susan A. O'Shaughnessy, Research Agricultural Engineer, USDA-ARS Conservation and Production Research Laboratory, Bushland, Texas; Derek M. Heeren, Associate Professor and Daugherty Water for Food Global Institute Faculty Fellow, University of Nebraska, Lincoln, Nebraska; Thomas J. Trout, Research Agricultural Engineer (retired), USDAARS Water Management and Systems Research Unit, Fort Collins, Colorado; William L. Kranz, Agricultural Engineer, Haskell Agricultural Laboratory, University of Nebraska, Concord, Nebraska; Xiaomao Lin, Associate Professor, Department of Agronomy, Kansas State University, Manhattan, Kansas. Corresponding author: Steven R. Evett, 300 Simmons Rd., Unit 10, Bushland, TX 79012; phone: 806-356-5775; e-mail: steve.evett@usda.gov.

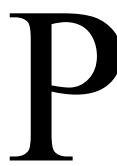

ast performance is often a good predictor of future performance. While it is difficult to find people with good records of predicting the future, this dictum can be applied to the people of the U.S. Great Plains and their social and political systems, including their interaction with the land through agricultural innovations influenced by a pioneering spirit. To have a chance at glimpsing and affecting future conditions, we must understand the past and the historical journey that has led to the present day. The historical journey involves initial recognition of natural resources and early attempts to exploit them in agriculture, through innovations to better use soil and water resources 
while minimizing resource loss, to water resource limitations imposed by the declining aquifer, and to recognition of the political necessity of some regulation of resource use in order to provide for sustainable rural communities. The cumulative effect of these efforts is that irrigation has a tremendous impact on the agricultural economy of the Great Plains, with irrigation from the High Plains aquifer in particular resulting in a $51 \%$ increase in biomass production and having an average gross annual value (as of 2007) of $\$ 3$ billion (Suarez et al., 2018). The goal of this article is to review the past and present status of irrigation, water supplies, and irrigation research in the Great Plains in order to provide perspective on the current situation and changes in water supplies, cropping patterns, irrigation methods and management, policy, and climate and how these may affect the future of irrigated agriculture in the Great Plains.

\section{GEOGRAPHICAL BACKGROUND}

The North American Great Plains extend from the provinces of Alberta, Manitoba, and Saskatchewan in Canada, where they are called the Prairies, southward through the Plains states and west Texas to the northern part of the state of Coahuila, Mexico. The western edge is delineated by the foothills of the Rocky Mountains, but the eastern edge is less clearly defined. A geophysical description by Trimble (1980) placed the eastern edge of the Great Plains within the eastern half of South Dakota and Nebraska and approximately in the middle of North Dakota and Kansas (fig. 1a). Others define the eastern margin of the U.S. Great Plains as occurring roughly along the eastern borders of North and South Dakota, Nebraska, Kansas, Oklahoma, and through central Texas (Miksinski, 1998).
Most soils in the region were formed from silt-textured loess deposited by winds in the Quaternary period, but the soils in some places were greatly modified by weathering to clay, formation of clay (Bt) and carbonate rich (caliche) layers, and erosion and deposition along stream and river valleys (Aandahl, 1982). Wind-blown sand deposits formed along some river valleys and areas downwind of erosional sources. The sand hills of Nebraska and sandy soils in some parts of eastern Colorado, southwestern Kansas, and the western Oklahoma and Texas Panhandles are examples of this soil genesis and reminders of past, much drier, climates. In general, the soils are nearly level and deep, with moderate to slow permeability and superactive clay content that holds nutrients well. The soils are often well suited for irrigation and quite productive when water is available.

River systems play important roles for irrigation in parts of Colorado, Montana, Nebraska, North and South Dakota, Wyoming, and parts of Kansas. The Missouri River and its tributaries are important in Montana, North and South Dakota, and Wyoming. In the Central Great Plains, there are two primary water sources for irrigation: rivers and reservoirs fed by snowmelt from the Rocky Mountains and delivered as surface water through canal systems, and the High Plains (Ogallala) aquifer (fig. 1b). Important rivers include the North and South Platte rivers, which join in Nebraska to form the Platte, the Republican, which flows from Colorado and Kansas into southern Nebraska and back into Kansas, and the Arkansas, which flows from Colorado into Kansas. The North Platte originates in Colorado and runs through Wyoming, where it is an important source of irrigation water, before entering Nebraska, while the South Platte also originates in Colorado, where it is also an important source of irrigation water, before it flows into Nebraska. In addition

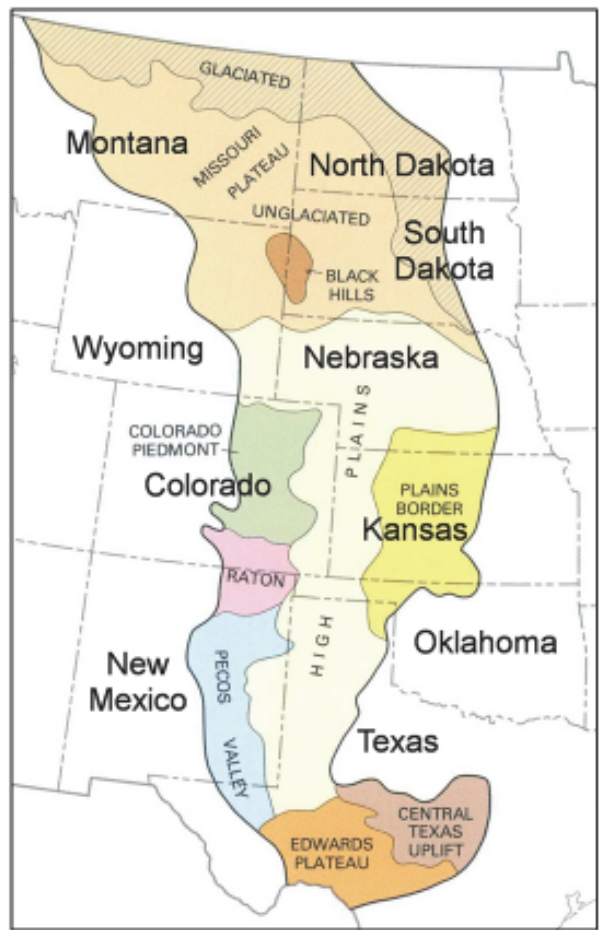

(a)

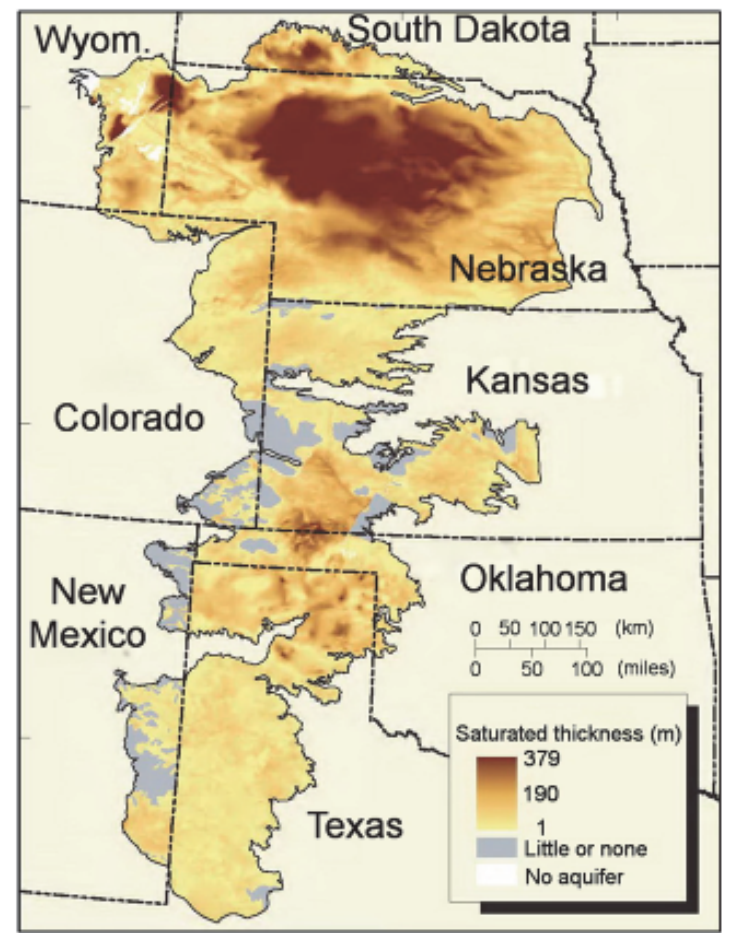

(b)

Figure 1. (a) Spatial coverage of the U.S. Great Plains (after Trimble, 1980) and (b) areas underlain by the High Plains aquifer with saturated thickness shown in meters (after Gurdak and Qi, 2006). 


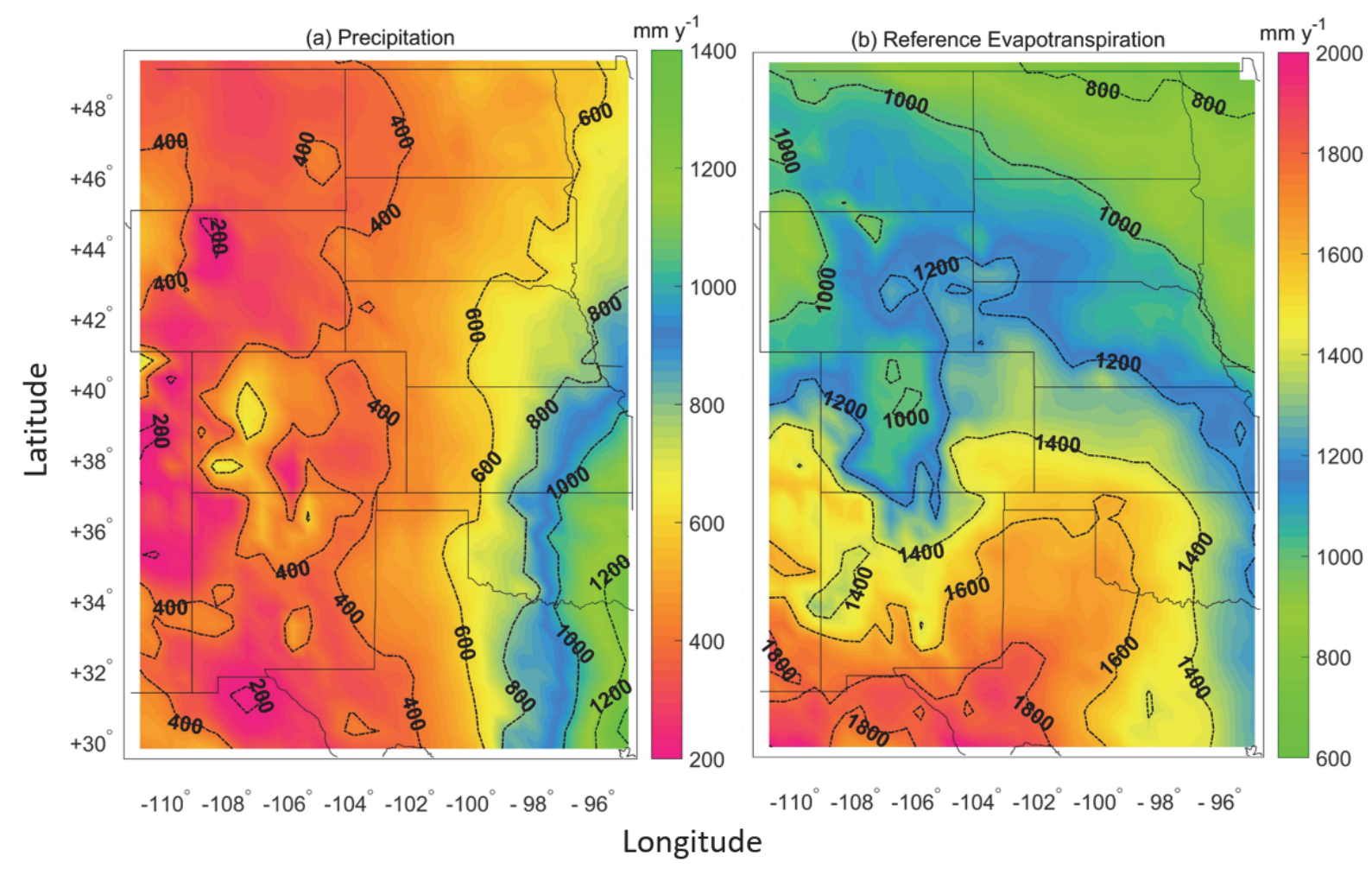

Figure 2. (a) Mean annual precipitation and (b) mean annual Penman-Monteith short crop reference evapotranspiration (ASCE, 2005) in the U.S. Great Plains for the period from 1981 through 2010 (data are from Harris et al., 2014).

to surface water diversions, pumping from shallow alluvial aquifers along river systems is important, as are the irrigation return flows to these systems.

Annual precipitation varies from approximately $700 \mathrm{~mm}$ along the eastern edge of the High Plains aquifer to $<300 \mathrm{~mm}$ in the western Great Plains (fig. 2a), with little variation from north to south, making the western half of the Great Plains a semi-arid region. Inter-annual precipitation variability is large, and the region is rendered even riskier for dryland agriculture by the large evaporative demand, which varies from approximately $1600 \mathrm{~mm}$ of pan evaporation in the eastern part to $>2400 \mathrm{~mm}$ in the most western parts of the Southern High Plains (Farnsworth et al., 1982). Perhaps more relevant for farming, reference evapotranspiration $\left(\mathrm{ET}_{o}\right)$ increases from the northeast to southwest in the Central and Southern Great Plains, being considerably less in the middle of Nebraska (1100 to $1200 \mathrm{~mm}$ ) than in southwestern Kansas and the Oklahoma and Texas Panhandles (1500 to $1800 \mathrm{~mm}$ ) (fig. 2b). Overall, evaporative demand is greater than precipitation by $200 \%$ to $500 \%$, explaining the pre-historical and current development of irrigation in the region and the emphasis on soil water management.

\section{IrRigation on the Great Plains:}

\section{Past to Present}

\section{AnCient Times to SeTtLer DAYS}

Irrigation has been practiced in the region since pre-historical times, then as now in response to the high evaporative demand and uncertain rainfall. Prehistoric irrigation occurred as diversions of surface waters in Kansas (Erhart,
1969) and in the Oklahoma and Texas Panhandles (Thoburn, 1926, 1931). Hispanic farmers and sheep herders initiated irrigated agriculture along the Canadian River in Texas, near Tascosa, in the 1870s (Nostrand, 1996; Green, 1973), which was approximately the time that historical agriculture began in the southern Great Plains. In Colorado, irrigation began along the Platte River in the early 1860 s to feed the growing population of miners, and South Platte River water rights were over-allocated before 1880 . One of the first recorded instances of irrigation in Nebraska dates back to 1870 near Fort Sidney, where a ditch from Lodgepole Creek brought water to gardens, lawns, and trees, and irrigation continued to be developed on a small scale (fig. 3, left). It was not until the 1930s that a significant investment was made to bring surface water to areas along the North Platte River in the Panhandle and west-central portions of Nebraska, e.g., the Central Nebraska Public Power and Irrigation District (Nebraska Water Center, 2018). In Colorado and Kansas, the first large Arkansas River ditch water right was the Rocky Ford ditch diversion in 1874 (van Hook, 1933), and more irrigation from diversion of the Arkansas River followed in the 1880s (Erhart, 1969). In South Dakota, the Belle Fourche Irrigation District was one of the first projects of the U.S. Bureau of Reclamation. With passage of the Reclamation Act in 1902, surveying of the Belle Fourche project area was done in 1903, and irrigation water delivery commenced in 1908.

In the plains of eastern Colorado and in Nebraska, surface water diversions began in the later 1800s. In response to water availability concerns, trans-basin diversions from the Colorado River to the Arkansas and Platte Rivers began in the 1880 s and were supplemented with large federal projects 

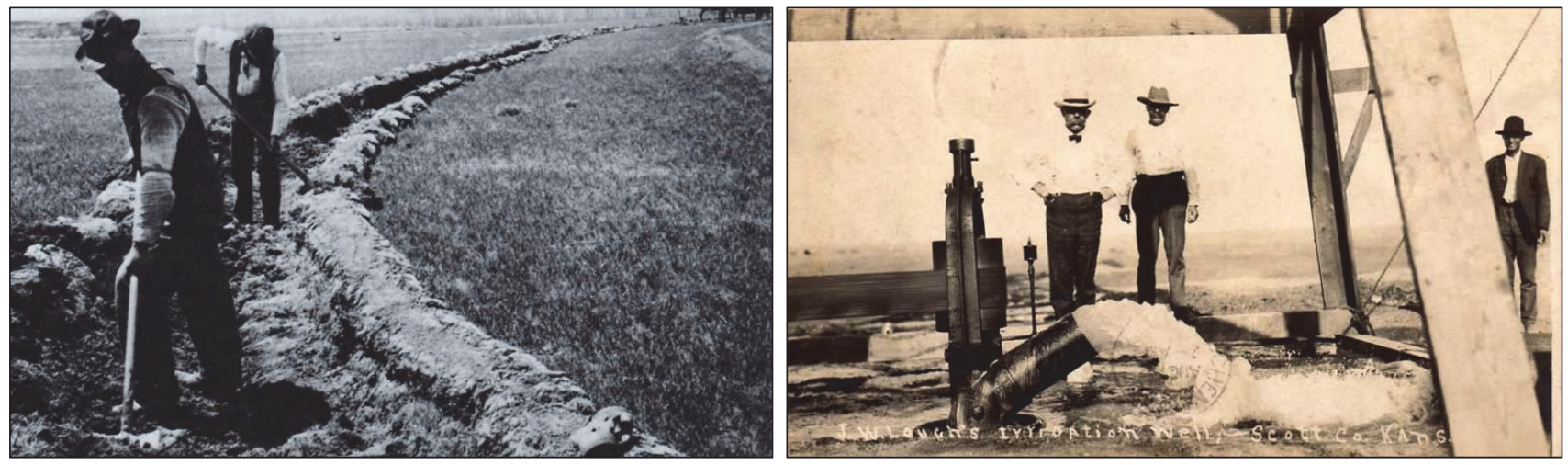

Figure 3. (left) Digging an irrigation canal by hand in the late 1800s in Nebraska (courtesy of the Iowa Irrigation Museum and the U.S. Bureau of Reclamation); (right) a groundwater well for irrigation in Scott County, Kansas, 1910 (courtesy of the Iowa Irrigation Museum and G. Bowlin).

in the 1930 s to 1960 s. Surface water storage also played a large role from the 1880 s (private) through the 20th century (federal and municipal projects) (CWCB, 2010, 2015; CFWE, 2014). A lack of knowledge about crop water consumptive use and river hydrology were factors in diverting more water than some rivers could reliably supply, which led to lawsuits and negotiations between the states that continue to the present in some cases and that have consequences for irrigation water availability.

In additional to surface water delivery systems, aquifers provided another source of water in the Great Plains (fig. 3, right). In the 1880s, irrigation from wells began in semi-arid western Texas, with steam or gasoline-powered pumps irrigating areas of 2 to 400 ha, and windmills irrigating areas of up to 3 ha (Hutson, 1898). Some pumping plants delivered $160 \mathrm{~L} \mathrm{~s}^{-1}$, enough for hundreds of irrigated hectares (Hutson, 1898). Hutson (1898) described well water availability as follows: Water "is reached by wells of from 40 to 200 feet $(12$ to $61 \mathrm{~m})$ in depth. Many of these wells are capable of furnishing a supply almost inexhaustible to ordinary means of pumping," a far cry from the depths of up to $300 \mathrm{~m}$ and well capacities of $<16 \mathrm{~L} \mathrm{~s}^{-1}$ common today.

The future of irrigation in the Texas Panhandle was described from the perspective of the 1890s by Hutson (1898): "Of the future of irrigation here in general, it may be said that there is opportunity for but the little indicated, at these widely scattered spots, but that this little will prove to be just that small amount needed for rendering practicable the utilization of the High Plains for stock raising, under conditions that will be bearable for those who have to live upon these great pasture lands for the conduct of the stock industry." Hutson would have been surprised by the rapid expansion of irrigation after 1940, but he may have been prescient about the future of irrigation in the Texas Panhandle and elsewhere on the Great Plains.

\section{RAPID EXPANSION AFTER 1940}

Large inter-annual variations in flow and upstream diversions of the Arkansas River slowed irrigation expansion in Kansas until the 1940s, when rapid expansion became possible due to the adoption of well drilling technologies from the oil industry and the availability of deep well pumps, internal combustion engines, and rapid expansion of the electrical grid (Green, 1973). In Nebraska, public power and ir- rigation districts obtained water rights to divert water from the Platte, Republican, Loup, Dismal, and Niobrara Rivers. Eventually, nearly 405,000 ha of land were irrigated using surface irrigation methods. Eight of these irrigation districts received surface water rights to deliver water to $>182,000$ ha of Nebraska farmland. Expansion of irrigation in the Great Plains was greatly motivated by the drought of the 1950s and aided by the soldiers returning from World War II, reaching a high point in Kansas of 1.42 million ha in 1980 before declining to approximately 1.21 million ha by 2000 (Rogers and Wilson, 2000). The pattern of expansion in Kansas was mirrored in the Texas Panhandle, reaching 2.4 million ha in 1974 before declining to 1.59 million ha by 1989 and then increasing to 1.87 million ha by 2000 (Colaizzi et al., 2009).

Regardless of surface water availability, as in Kansas, Oklahoma, and Texas from the 1940s forward, irrigation expanded rapidly elsewhere in the Central Great Plains wherever the aquifer was available and the soils and terrain were suitable for irrigation (Ganzel, 2009). In Nebraska, interest in irrigation was shared by those too far from the Platte River to receive water via the extensive system of canals and reservoirs. Although irrigation wells were drilled to pump groundwater beginning in the 1930s, rapid expansion really began after 1945. By 1969, nearly 1.2 million ha were irrigated and 33,000 registered wells had been drilled in Nebraska alone. Since that time, there has been a steady increase in registered irrigation wells, which now total over 96,500 in Nebraska (NDNR, 2018). As the number of irrigation wells increased, so did the irrigated area. According to the 1930 Census of Agriculture, just over 162,000 ha of land were irrigated in Nebraska. By 1964, the number had risen to 850,000 ha. The 2013 USDA-NASS Farm and Ranch Irrigation Survey listed 3.36 million ha of irrigated land in Nebraska, the largest irrigated area of any U.S. state.

From 1998 to 2008, the irrigated area in the ten states overlying the High Plains aquifer increased by $11 \%$ but declined since 2008 by $7 \%$ to 9 million ha in 2018 (table 1) (USDA-NASS, 1998, 2008, 2013, 2019a). Irrigation expansion was most notable in Nebraska, where the irrigated area increased by $46 \%$ between 1998 and 2013 before declining slightly to 3.1 million ha in 2018. Decreases in irrigated area in the 20 years since 1998 were greatest in Colorado (-18\%) and Texas (-22\%), while Kansas lost $10 \%$ of its irrigated area. In Colorado, decreases in irrigated area are tied to water 
Table 1. Irrigated area, mean depth of water applied, and percentage of the irrigated area that depends on groundwater in the ten Great Plains states overlying the High Plains aquifer in 1998, 2008, 2013 and 2018, ranked by irrigated area in 2018. (USDA-NASS, 1998, 2008, 2013, 2019a).

\begin{tabular}{|c|c|c|c|c|c|c|c|c|c|c|c|c|c|}
\hline \multirow[b]{2}{*}{ State } & \multicolumn{4}{|c|}{$\begin{array}{l}\text { Irrigated Area } \\
\text { (ha) }\end{array}$} & & \multicolumn{4}{|c|}{$\begin{array}{c}\text { Depth of Water Applied } \\
(\mathrm{mm})\end{array}$} & \multicolumn{4}{|c|}{$\begin{array}{c}\text { Percentage of Irrigated Area } \\
\text { Dependent on Groundwater } \\
(\%)\end{array}$} \\
\hline & 2018 & 2013 & 2008 & 1998 & & 2018 & 2013 & 2008 & 1998 & 2018 & 2013 & 2008 & 1998 \\
\hline Nebraska & $3,102,274$ & $3,357,977$ & $3,331,418$ & $2,303,608$ & & 193 & 296 & 243 & 266 & 91 & 92 & 94 & 89 \\
\hline Texas & $1,652,515$ & $1,817,882$ & $2,110,132$ & $2,119,621$ & & 399 & 394 & 388 & 435 & 83 & 90 & 87 & 87 \\
\hline Kansas & 965,776 & $1,153,912$ & $1,035,545$ & $1,072,637$ & & 314 & 367 & 372 & 413 & 96 & 98 & 97 & 97 \\
\hline Colorado & 994,767 & 934,659 & $1,109,453$ & $1,190,704$ & & 476 & 546 & 490 & 523 & 47 & 43 & 43 & 45 \\
\hline Montana & 865,979 & 757,745 & 735,328 & 704,522 & & 363 & 407 & 419 & 505 & 3 & 3 & 2 & 3 \\
\hline Wyoming & 631,920 & 573,972 & 572,963 & 620,586 & & 443 & 449 & 617 & 553 & 11 & 10 & 7 & 6 \\
\hline New Mexico & 273,200 & 281,114 & 322,431 & 291,509 & & 604 & 575 & 696 & 732 & 58 & 58 & 66 & 59 \\
\hline Oklahoma & 243,415 & 172,643 & 184,756 & 182,836 & & 335 & 373 & 345 & 457 & 83 & 88 & 83 & 79 \\
\hline South Dakota & 153,096 & 149,682 & 144,904 & 120,277 & & 211 & 240 & 229 & 320 & 55 & 65 & 57 & 46 \\
\hline North Dakota & 120,192 & 86,495 & 98,367 & 66,670 & & 195 & 212 & 275 & 260 & 64 & 73 & 68 & 63 \\
\hline Total: & $9,003,135$ & $9,286,081$ & $9,645,297$ & $8,672,970$ & Mean: & 353 & 386 & 407 & 446 & & & & \\
\hline
\end{tabular}

availability decreases, which are mostly due to overallocation and competition from municipal users, coupled with aquifer declines and interstate and intrastate agreements. In Texas and Kansas, water availability is decreasing, almost entirely due to aquifer declines in those states, which rely on groundwater for irrigation on $83 \%$ and $96 \%$ of irrigated land, respectively. Substantial increases of irrigated area in Montana (162,500 ha) and North Dakota (53,500 ha) are largely due to expansion in the MonDak region, which comprises the lower Yellowstone River and Missouri River area of eastern Montana and western North Dakota. The MonDak region is the only sizeable area in the U.S. Great Plains that still has unappropriated water available for irrigation expansion. This region has potential for further irrigation expansion of $>200,000$ ha (USDA-ARS, 2019).

In 2018, groundwater was by far the most common source of water for irrigation in the three states with the most irrigated area, serving $91 \%$ of the irrigated area in Nebraska, $83 \%$ in Texas, and $96 \%$ in Kansas (table 1). The percentage is close to $100 \%$ in Texas if only the Southern High Plains region is considered. In contrast, Colorado relies more on surface water supplies, and Wyoming and Montana rely almost entirely on surface water. The percentage of irrigated area dependent on groundwater in Colorado is considerably greater than the $47 \%$ given in table 1 if we consider only the Great Plains area east of the Rockies. The percentages of irrigated land dependent on groundwater were largely unchanged over 20 years in the Great Plains states. Although conversion to more efficient irrigation systems and to crops that require less water has resulted in an overall $21 \%$ decline in seasonal irrigation applications, from $446 \mathrm{~mm}$ in 1998 to $353 \mathrm{~mm}$ in 2018, the percentage of decline varied by state. For example, seasonal irrigation application in Nebraska increased by $11 \%$ from 1998 to 2013 before declining to $193 \mathrm{~mm}$ in 2018. Application depths remained fairly constant from 1998 to 2013 in Colorado before declining to $476 \mathrm{~mm}$ in 2018. And applications decreased by $8 \%$ in Texas and $24 \%$ in Kansas over the 20 -year period. In general, the states that rely more on surface water had greater depths of applied irrigation than the states that rely mostly on groundwater ( $419 \mathrm{~mm}$ vs. $287 \mathrm{~mm}$ in states with $>60 \%$ of area irrigated with groundwater). Because producers who pump groundwater are largely using center-pivot irrigation, while many who rely on surface water are still using gravityflow irrigation, the greater water use for irrigation with sur- face water sources is likely tied to the lower application efficiencies of gravity systems. Greater water use may also be caused by policy management difficulties with surface water deliveries. Withdrawals for irrigation have severely depleted the High Plains aquifer south of the Platte River, particularly in southwestern Kansas and the Texas and Oklahoma Panhandles (fig. 4).

\section{Changes in IrRigation Methods}

In 1940, irrigation was provided by surface application using furrows, borders, or flooding from ditches, also known as gravity irrigation. Water loss due to runoff or percolation below the root zone led to reduced water for crops and relatively small yields per unit of water applied. Seepage losses in unlined canals and ditches were also important, as was waterlogging of plants near canals or the lower end of furrows. Uneven furrow flows resulted from the manual distribution into furrows via V-notches cut into the earthen channels or distribution ditch walls. This problem was addressed by the advent of the irrigation siphon tube, which quickly became popular due to the more uniform distribution and dependable flow into each furrow that it offered and the fact that it could be used with concrete-lined canals, which were being encouraged to reduce seepage losses and waterlogging of crops. In 1945, plastic siphon tube manufacturing began in Nebraska (Ganzel, 2009).

The siphon tubes required a lot of labor and could only be used with open ditches and relatively debris-free water. In addition, concrete lining of canals was expensive and did not stop all seepage losses. Canals also were not suitable for some farm layouts and reduced the irrigated land area to that which was downhill from the water source, resulting in a trend to install underground pipelines to eliminate seepage losses and route water more easily to irrigable land. Although pressures in these pipe systems were small, this was the advent of pressurized water delivery. With pressurized water, gated pipe became popular as an alternative to siphon tubes and remains popular to this day in some locations. In later years, many attempts were made to mechanize surface irrigation to reduce labor requirements. For example, cablegation moves a plug down a gated pipe using a clocking mechanism, resulting in a continuously moving irrigation set across the field (Kemper et al., 1981); however, cablegation was never widely adopted in the U.S., with only about 100 systems installed by 1990 (Trout and Kincaid, 1994; 


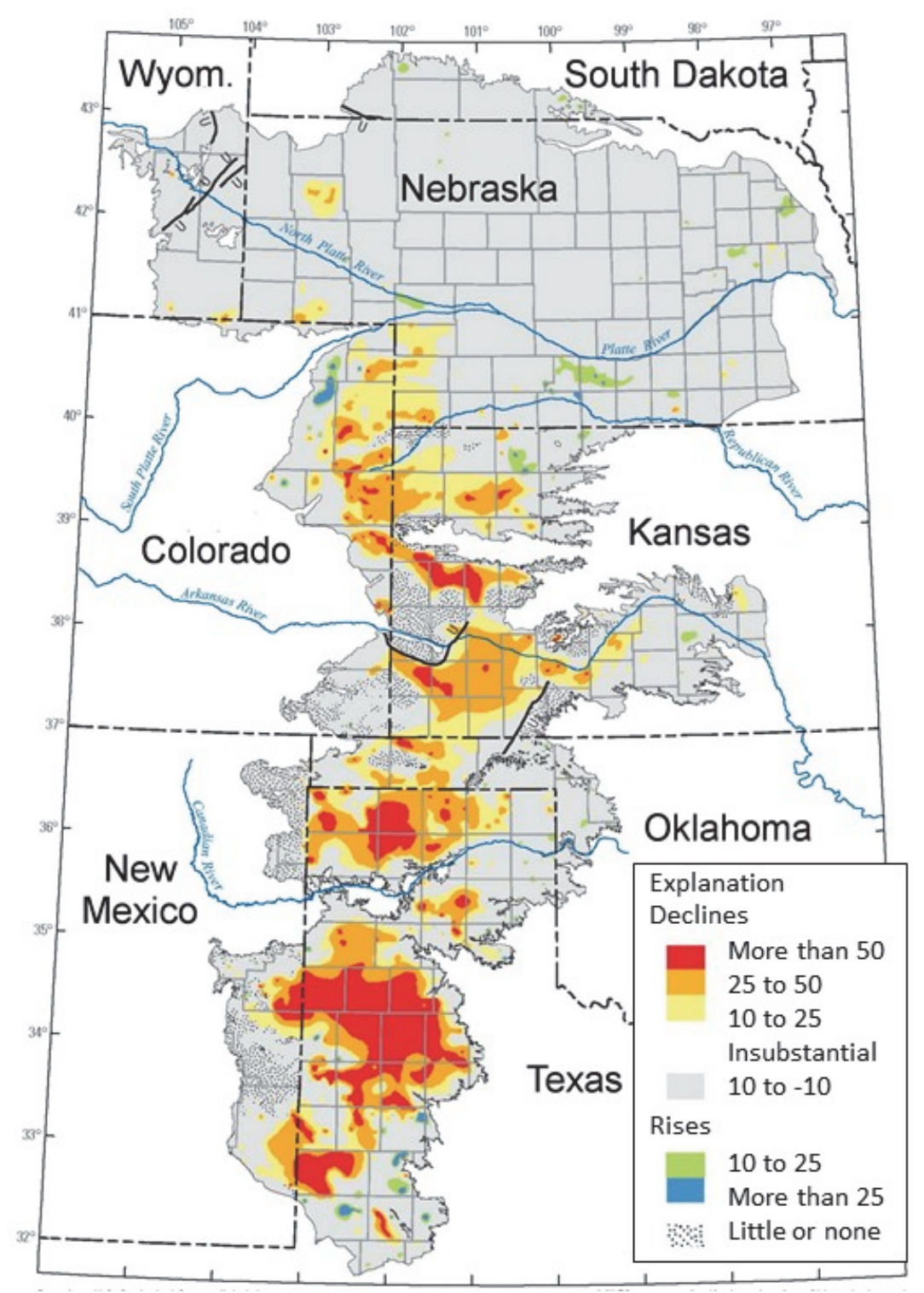

Figure 4. High Plains aquifer saturated thickness changes in feet (after McGuire, 2014).

Trout et al., 1990). After World War II, the pressurization of irrigation systems began to increase with the advent of moving irrigation systems.

In 1948, Frank Zybach in Colorado invented the centerpivot sprinkler irrigation system, taking advantage of pressurized water delivery (Heermann and Hein, 1968; Kincaid et al., 1969). At that time, irrigation through sprinklers mounted on portable pressurized pipes was available, though not widely used in the Great Plains. During and after World War II, labor became more difficult to find due to wartime manpower needs and post-war urbanization. As a self-moving system, the center-pivot sprinkler solved this labor problem, as well as the problems of seepage and deep percolation losses in gravity-flow surface irrigation systems. It could also be used on land with complex topography without land leveling, making more land irrigable. Runoff on sloping lands may occur with center-pivot irrigation but can be substantially reduced through appropriate applicator selection and placement, or with sprinkler boom systems that offer decreased point application intensities. Interactions between sprinkler type and runoff were addressed by research in South Dakota on sprinkler patterns, droplet characterization, and runoff (Kohl and DeBoer, 1984; DeBoer and Chu, 2001).

Early development of the center-pivot industry was especially strong in Nebraska (Nebraska Water Center, 2018). In Nebraska, the total number of pivots was less than 2700 in 1972 but had increased to nearly 12,000 by 1976 based on remote sensing studies conducted by the University of Nebraska Remote Sensing Center (UNL, 1977). The 2002 Farm and Ranch Irrigation Survey showed just over $72 \%$ of the irrigated area in Nebraska was irrigated by sprinklers (USDA-NASS, 2002). That number increased by $6 \%$ in just five years to 78\% (USDA-NASS, 2008), and in 2018 the estimate was that $91 \%$ of the irrigated acres in Nebraska were irrigated with sprinkler systems (USDA-NASS, 2019a), almost exclusively center pivots, which numbered more than 55,000 . As of 2018 , more than $85 \%$ of the irrigated area in the Southern High Plains was served by such systems (USDA-NASS, 2019a). The land area percentage in Kansas 
with center-pivot sprinkler irrigation increased from approximately $50 \%$ in 1990 to nearly $92 \%$ by 2012 (Rogers and Lamm, 2012).

Interest in subsurface drip irrigation (SDI) for the Great Plains region started in the 1960 s, with SDI research for cotton in Texas reported as early as 1963 (Zetzsche and Newman, 1966). By the late 1980s, interest in the region and the rest of the U.S. began to increase rapidly, particularly in water-short areas (Camp and Lamm, 2003). Although the land area devoted to SDI in the Great Plains is still small compared to center-pivot sprinkler irrigation, the SDI area continues to grow, particularly in Texas for cotton production. The current estimated SDI land area in the U.S. is approximately 450,000 ha, with approximately $25 \%$ of that area in Texas, Nebraska, and Kansas (USDA-NASS, 2019a).

As of 2018, pressurized systems supplied water to $65 \%$ of the irrigated area in the U.S. (USDA-NASS, 2019a). Pressurized systems now supply water to $85 \%$ to $90 \%$ of Great Plains irrigated area. These systems eliminate most losses during conveyance to the field and greatly reduce the irrigation nonuniformity that was due to spatially variable infiltration capacity and water distribution by overland flow processes with surface gravity-flow irrigation.

\section{IRRIGATION RESEARCH ADVANCES EFFICIENCY AND PRODUCTIVITY}

As irrigation rapidly developed, it was increasingly recognized that water resources are finite, and research was aimed at developing and promoting methods for water conservation. Our examination of irrigation research focuses on advances in the efficiency and productivity of irrigation systems, which serve as a link between irrigated agriculture and its impact on water resources. We conceptualize these advances with the following metrics, which are commonly used in the irrigation community:

$$
\begin{array}{r}
\mathrm{AE}=\frac{I_{E}}{I_{A}} \\
\mathrm{CWP}=\frac{Y}{\mathrm{ET}} \\
\mathrm{IWP}=\frac{Y-Y_{r}}{I_{A}}
\end{array}
$$

where

$\mathrm{AE}=$ irrigation application efficiency (fraction)

$I_{E}=$ depth of effective irrigation (L) remaining in the root zone after application and available for crop uptake

$I_{A}=$ depth of applied irrigation $(\mathrm{L})$

$\mathrm{CWP}=$ crop water productivity $\left(\mathrm{M} / \mathrm{L}^{3}\right)$

$Y=$ marketable yield $\left(\mathrm{M} / \mathrm{L}^{2}\right)$

$\mathrm{ET}=$ crop evapotranspiration $(\mathrm{L})$

IWP $=$ irrigation water productivity $\left(\mathrm{M} / \mathrm{L}^{3}\right)$

$Y_{R}=$ marketable yield of a rainfed or dryland crop $\left(\mathrm{M} / \mathrm{L}^{2}\right)$.

Of the three metrics, only AE is an efficiency in engineering terms. The AE is typically focused on the irrigation event and is a way to quantify efforts to minimize losses during irrigation application (due to evaporation, drift, canopy interception, runoff, and deep percolation) and can also be used to characterize seasonal performance. The CWP (also known as water use efficiency, WUE) is a way to characterize efforts to increase $Y$ relative to the amount of crop consumptive use (ET). The IWP is a productivity metric that uses gross irrigation applied; it reflects only the additional yield gained by irrigating compared with rainfed or dryland production. Because of variability in rainfed or dryland yield, the IWP can be quite variable among seasons and locations, and it may take many years of data to obtain useful knowledge from this metric. Producers have a management goal of maximizing net profit. In some cases, improving the AE, CWP, and/or IWP will increase profits, while in other cases improving the efficiencies is a way to promote water resource stewardship within the constraint of remaining profitable.

The CWP is the only one of the three metrics that correlates directly to consumptive use, i.e., water that is consumed and does not remain available in the watershed. Consumptive use is a key concept for basin-scale sustainability of water quantities (Allen et al., 2003). In some cases, improvements in the AE or IWP are due to reducing runoff or deep percolation, which are not consumptive uses. Reducing runoff and deep percolation may decrease water availability to downstream users, but runoff and deep percolation reductions are valuable in terms of reducing negative impacts on water quality, reducing evaporation of runoff, and reducing energy costs for pumping irrigation water. When management practices to improve the AE, CWP, and/or IWP are promoted, it is helpful to clarify the specific benefits of the management practices (Allen et al., 2003), an issue that was recently highlighted in Science (Grafton et al., 2018).

As early as 1911, irrigation research programs were established at several Great Plains research stations (e.g., at Akron and Fort Collins, Colorado, in 1911, and Amarillo, Texas, in 1938) to seek ways to improve irrigation efficiencies and to improve crop water productivities as irrigation expanded. Research on crop water requirements began in Akron, Colorado, in 1911 using small above-ground lysimeters (Briggs and Shantz, 1914). Crop water use was determined by soil water balance in most dryland and irrigated experiments, at first by taking soil cores but later using the neutron probe (NP). As early as 1959, the USDA-ARS at Bushland, Texas, was involved in the early trials and development of the NP (Hauser, 1959), an involvement in soil water sensor development that continues to this day.

By the 1970s, farmers were adopting methods from research reports for tailwater retention and utilization for furrow irrigation (Fischbach and Somerhalder, 1971; Schneider, 1976), retention of surface crop residues to reduce evaporative losses (Unger, 1976; Unger and Wiese, 1979), and stubble mulch tillage of irrigated wheat (Allen et al., 1976). Research continues to document the benefits of surface residue in irrigated systems in the Great Plains (Klocke et al., 2009; Lamm et al., 2009; van Donk et al., 2010; Haghverdi et al., 2017) and to update crop coefficients for residue (Odhiambo and Irmak, 2012). These methods of water conservation increased the yields produced per unit of water pumped, largely by reusing runoff water and reducing evaporative losses. Surge irrigation was also investigated as a way to improve application efficiency for furrow irrigation 
in Colorado (McCornick et al., 1988) and Nebraska (Yonts et al., 1996).

As water table depths and well yields declined, limited irrigation of sorghum and sunflower was shown to improve the overall CWP due to both reduction of evaporative losses and more effective use of rainfall (Stewart et al., 1983; Unger, 1983). However, too much reduction of irrigation was shown to be harmful for corn and soybean (Eck, 1986; Eck et al., 1987; Musick and Dusek, 1980). Alternate-furrow irrigation was shown to reduce water supply needs but not yields for corn and sorghum in Texas, resulting in increased CWP (Musick and Dusek, 1982), and for soybean in Nebraska (Graterol et al., 1993), mostly through reduction of the wetted surface soil area and thus reduction of evaporative losses. Still, inefficiency in furrow irrigation led to furrow compaction research that demonstrated reduced losses to deep percolation, although this effect was soil-specific $(\mathrm{Mu}-$ sick et al., 1985; Musick and Pringle, 1986). In the ten years from 1974 to 1984, average irrigation applications were reduced from 404 to $350 \mathrm{~mm}$ in Texas by adoption of these methods, plus reduced pre-plant irrigations, and in some cases by shifting to crops more compatible with limited irrigation (Musick and Walker, 1987). Pre-plant, pre-season, or dormant-season irrigation is sometimes practiced in the Great Plains region as a means of extending marginal well capacities through droughty conditions by increased soil water storage within the profile. However, although it may have merit under these conditions, it often has small overall application and storage efficiencies (Lamm and Rogers, 1985; Musick and Lamm 1990; Stone et al., 2008).

Although the transition from gravity irrigation methods to pressurized sprinkler irrigation generally increased onfarm application efficiency, evaporative losses from the high-pressure impact sprinklers of the 1950s and 1960s limited further advances. The mid-1980s saw progress in application efficiencies with the introduction of furrow-diking and low-energy precision application (LEPA) technology for moving irrigation systems (Howell, 1997). Moving systems replaced solid set (stationary) systems so that, by 1984, $37 \%$ of the total irrigated area in the Texas High Plains was irrigated by moving systems (Musick and Walker, 1987). LEPA technology became more important by the end of the 1980s as the gravity-irrigated area continued to decline, particularly on more permeable soils (Musick et al., 1988). By 1990 , the percentage of sprinkler-irrigated land had increased to $44 \%$ in the northern Texas Panhandle (Musick et al., 1990). Irrigation application efficiencies increased from the less than $60 \%$ achieved with gravity irrigation to $>80 \%$ with impact sprinklers in the Texas Panhandle and elsewhere on the Great Plains (Musick et al., 1988). Lyle and Bordovsky (1983) demonstrated consistent application efficiencies of $>95 \%$ with LEPA systems in furrow-diked fields. Adoption of the complete LEPA management system varied across the Great Plains. A historical discussion of the LEPA system and its technological advances is provided by Bordovsky (2019). Variants that included in-canopy and nearcanopy spray applications are more prevalent in the Central Great Plains due to greater land slopes and well capacities (Howell, 2006a; Lamm et al., 2006, 2007, 2019a). The popularity of center pivots also created an opportunity to irrigate with mobile drip irrigation systems in an effort to reduce energy consumption and evaporative losses. Known as "irrigation trail tubes" at the time, these systems were developed and tested in South Dakota (Chu et al., 1992) and in California (Phene et al., 1985) in the early 1980s, and even as early as the 1970s (Rawlins et al., 1974). The advent of pressurecompensated drip emitters engendered a resurgence of interest in what is now known as mobile drip irrigation (Kisekka et al., 2016).

While overall farm IWP, and in some cases CWP, increased with these improvements in application methods, it did not directly translate to reductions in water pumping. Rather, declining well capacities, due to the reduced saturated thickness, decreased water availability and increased the motivation to develop more efficient equipment and practices. New (1986) remarked that "center pivots improve water application efficiency enough to irrigate $20 \%$ to $25 \%$ more area than can be covered with furrow irrigation with the same water." By 1990, the water storage in the High Plains aquifer was estimated to have declined by $30 \%$ compared to predevelopment (Musick et al., 1990), motivating a continued search for ever more efficient irrigation methods and improved CWP in cultivars and irrigation management.

\section{Irrigation Improves CWP}

Irrigation improves the overall CWP (WUE), as was demonstrated by Musick et al. (1994), who summarized 178 field seasons of irrigated and dryland wheat data from Bushland, Texas, in terms of water use, grain yield, and CWP. Maximum yields required 650 to $800 \mathrm{~mm}$ of water, a quantity that was only available with irrigation. Importantly, the CWP for irrigated production was about double that for dryland production; and the relationship for CWP versus yield showed that, up to a point, high yields were necessary for efficient water use (fig. 5a). The regression line indicated that the rate of increase in CWP became less strong as yields increased. Except for a few seasons, the CWP of irrigated production was greater than that of dryland production (fig. 5b). This pattern would be expected for other climatecrop combinations where a significant amount of ET is required before a crop is able to produce any harvestable yield but precipitation is lacking during key growth stages. In such cases, irrigation allows the crop to leverage the ET that has already occurred to produce much additional yield with only a moderate amount of additional ET.

Further improvements in yield and CWP in irrigated winter wheat and dryland sorghum rotations were demonstrated for no-till as opposed to other tillage methods such as disk and sweep tillage (Unger and Wiese, 1979; Unger, 1984). Although a combination of pricing and yield has led to corn supplanting sorghum on much land in the Great Plains, there have been continued increases in sorghum yields (fig. 6). Unger and Baumhardt (1999) attributed $46 \%$ of the sorghum yield increase from 1939 to 1998 to improved hybrids and the rest to improved soil water content at planting time, which was due to the adoption of limited tillage and no-till practices made possible by improved herbicides. In Colorado, reduced tillage was shown to increase snow capture and thus soil water at planting, also resulting in improved yields (Nielsen, 1998). 
(a)

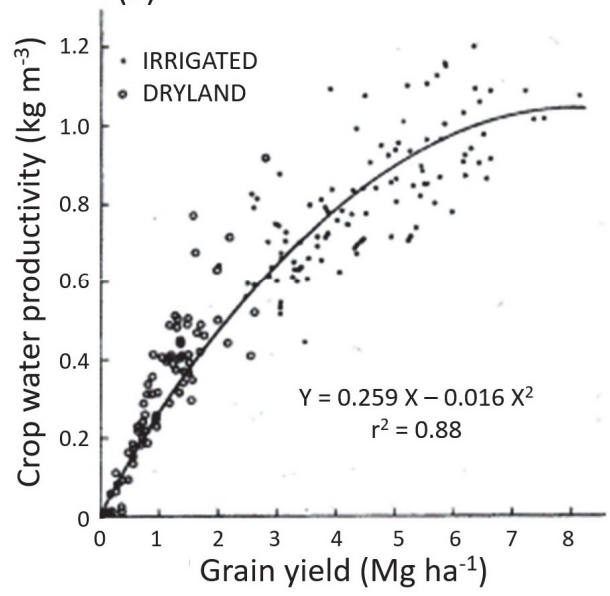

(b)

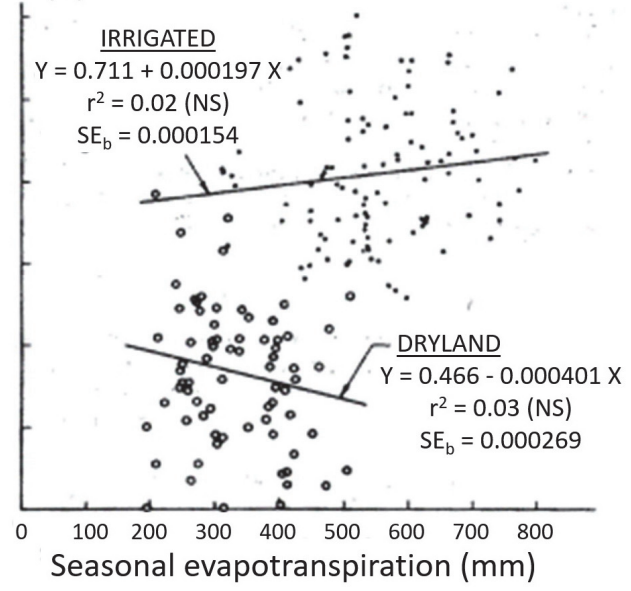

Figure 5. (a) Winter wheat crop water productivity was about doubled by irrigation compared to dryland production, and mean yield was more than doubled. (b) In the 400 to $500 \mathrm{~mm}$ range of water use, water use under dryland conditions was equal to that under irrigated conditions, but crop water productivity and yields were doubled with irrigation. Data are from 178 treatment years at Bushland, Texas (Musick et al., 1994). Grain yield is reported at $12.5 \%$ water content.

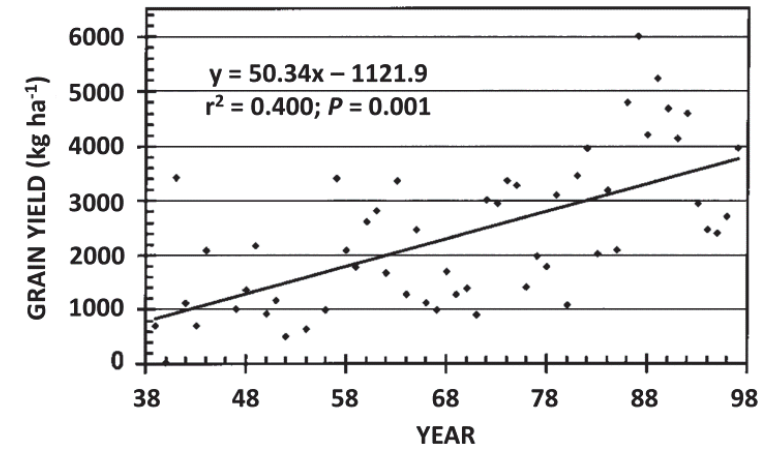

Figure 6. Dryland sorghum yields in the Texas High Plains steadily increased by an average of $50 \mathrm{~kg} \mathrm{ha}^{-1}$ annually since 1939 (Unger and Baumhardt, 1999).

As with winter wheat, compilation of data from many studies (352 treatment years between 1960 and 2010) has shown that irrigation of sorghum generally doubled not only yield but overall CWP (Evett et al., 2013). Sorghum CWP and yield were increased when irrigation was used to supplement precipitation and soil water storage at planting, and the greatest CWP values were obtained with deficit irrigation practices (fig. 7). The greatest sorghum yields also were obtained with deficit irrigation (fig. 7a), indicating that full ir- rigation to meet crop water demand can result in excessive vegetative growth, increased ET (fig. 7b), and smaller harvest index. Evidence for this was presented as early as 1957 by Jensen and Sletten $(1957,1958)$, who reported that hybrid sorghum yield declined at the highest water use rate.

Research has continued to investigate deficit irrigation, not only as a voluntary best management practice but also as a management practice to enable producers to optimize profit within the constraint of a limited water supply. Heeren et al. (2011) simulated irrigated corn production at several locations across the Great Plains and recommended deficit irrigation strategies based on stress timing for various levels of water limitation. Research in Nebraska developed Water Optimizer, a spreadsheet tool for pre-season planning for deficit irrigation, including which crops to grow and whether to leave a portion of the field under rainfed conditions (Martin et al., 1984, 2010, 2017). Field research in west-central Nebraska evaluated deficit irrigation for corn (Payero et al., 2009) and soybean (Payero et al., 2005). A review of deficit irrigation in the Great Plains is provided by Rudnick et al. (2019).

\section{Application Methods}

Irrigation research in the 1990s and thereafter reflected the search for ever more efficient application and management methods and the use of these methods to increase CWP
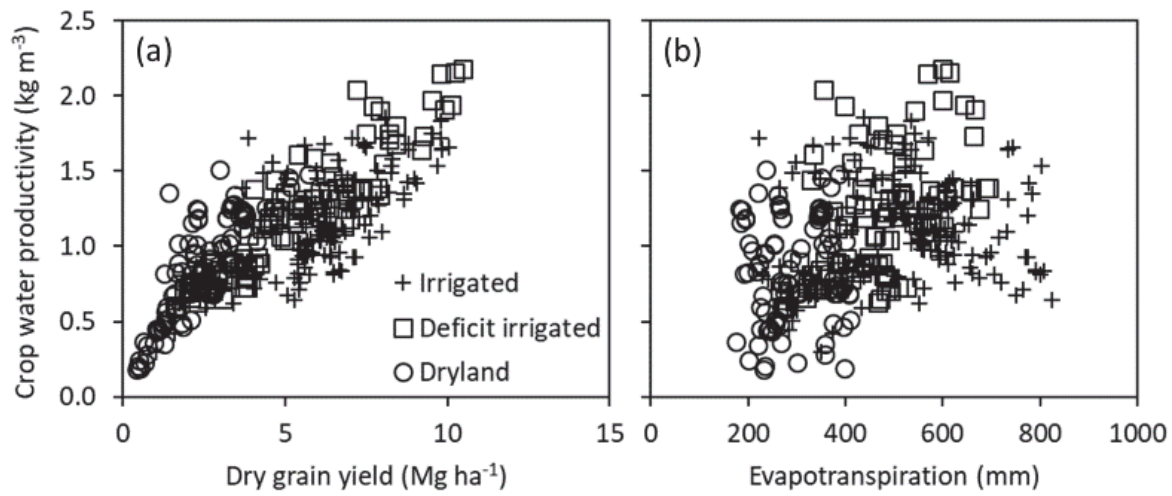

Figure 7. Sorghum crop water productivity (a) versus yield for full irrigation, deficit irrigation, and dryland practices, and (b) versus evapotranspiration. Data are for 352 treatment years between 1960 and 2010 on soils in the Texas Panhandle and Kansas (Evett et al., 2013). 
by reducing evaporative losses and increasing the ratio of transpiration (T, which is related to yield) to total water use (Schneider and Howell, 1993, 1994, 1995b, 1998, 1999). Earlier work focused on LEPA systems (Schneider and Howell, 1995a; Schneider, 2000; Schneider et al., 2000), but later spray, LEPA, and SDI methods were compared (Colaizzi et al., 2004; Schneider et al., 2001). SDI was often shown to have advantages where well capacities did not allow full irrigation (Lamm et al., 2010). SDI, which is a type of microirrigation, first began to be adopted to an important extent in the Great Plains cotton industry near Lubbock, Texas. SDI was also shown to be feasible and profitable for corn in the Kansas and Texas High Plains (Lamm et al., 1995, Howell et al., 1997a; Lamm and Trooien, 2003). Compared with spray sprinkler irrigation, drip irrigation was shown to be more efficient and to improve CWP due to the smaller wetted soil surface area (Evett et al., 1995, 2019).

Texas has the largest usage of SDI for cotton in the U.S., with 4,263 SDI systems covering 107,356 ha reported in 2013 for the High Plains Water District alone (HPWD, 2014). Cotton and to a lesser extent field corn constitute the bulk of the current SDI land area in the Central and Southern Great Plains, but the land area is still small compared to center-pivot sprinkler irrigation. Nevertheless, there are numerous published and ongoing SDI studies with these crops at research centers across the region. Many of the published studies were highlighted in a recent comprehensive review of SDI for cotton and corn along with tomato and onion for other regions (Lamm, 2016).

\section{Irrigation Scheduling}

With the increasing adoption of pressurized irrigation methods, research turned to more accurate irrigation scheduling as a means to improve overall water use efficiency by reducing deep percolation and evaporative losses, and by avoiding "luxury" consumption of water over the amount needed for optimal yields. This shift in focus is reflected in irrigation scheduling being the most common topic of proceedings papers for the first 14 years (1989-2002) of the Central Plains Irrigation Conference (https://www.ksre.kstate.edu/irrigate/oow/cpiadocs.html), which was formed as a technology transfer effort to increase "the knowledge and skills of those involved in irrigation" (Heermann and Lamm, 2003). Early work on irrigation scheduling in Colorado, $\mathrm{Ne}$ braska, North Dakota, and South Dakota emphasized the soil water balance (e.g., the checkbook method), soil water sensing, and crop canopy sensing (Heermann et al., 1976; Martin et al., 1990; Werner et al., 1993).

Water use for well-irrigated crops was determined by the soil water balance using neutron probes or soil coring to determine deep profile water contents at several research locations in the Central Plains. At the USDA-ARS Conservation and Production Research Laboratory (CPRL), these methods were supplemented with four large weighing lysimeters for direct crop water use measurements (Marek et al., 1988) in dryland, irrigated, and deficit irrigated regimes. Since 1987 and continuing today, these lysimeters have been used to determine the crop water use, crop coefficients for irrigation scheduling, and CWP of fully and deficit irrigated alfalfa, corn, cotton, sorghum, soybean, sunflower, and winter wheat; for some of these crops, the dryland water use was also determined (Evett et al., 2016). The Bushland lysimeters served as models for lysimeters to determine ET at Rocky Ford, Colorado; Uvalde, Texas; Parlier, California, and in China, Egypt, and Jordan (Andales et al., 2009, 2010; Evett et al., 2009; Marek et al., 2006; Schneider et al., 1993, 1998).

A partnership of Texas A\&M AgriLife Research and Extension with the USDA-ARS at Bushland, Texas, established a network of weather stations covering the Texas Panhandle beginning in 1995 to provide the data needed to estimate daily crop water use for all producers and all major crops in the region (Marek et al., 1996). What became the Texas High Plains Evapotranspiration Network stretched from Pecos at the southwest edge of the Plains, to Munday and Chillicothe in the Rolling Plains on the east, and to Dalhart and Perryton in the north. Daily crop water use estimates were provided for the major crops currently growing in the region, with separate values of ET for three to four planting dates (for annual crops) and with growth stage estimates. Data were delivered directly to producers by e-mail and fax and were available on the internet. Estimates of crop ET were based on the crop coefficients determined at the USDA-ARS-CPRL and daily reference ET values calculated from the weather data using the Penman Monteith equation (ASCE, 2005; Evett et al., 2000b; Howell et al., 1997b, 1998, 2004). The crop coefficients were determined by the USDA-ARS team, which also made important contributions to the ASCE Penman-Monteith standardized reference ET equations (ASCE, 2005). Similar efforts have been established in Colorado. Kansas has been providing ET estimates for irrigation scheduling by radio since the late 1970s (probably 1978) and through both radio and internet since 2000. In 2005, the Nebraska Agricultural Water Management Demonstration Network (NAWMD) began helping producers improve irrigation management using both soil moisture and ET (Irmak et al., 2010).

There are currently $\sim 600$ weather stations in the Great Plains producing daily estimates of reference ET for irrigation scheduling. The weather station networks include the North Dakota Agricultural Weather Network (NDAWN) with 91 stations, the Colorado Meteorological Network (CoAgMet) with 107 stations, of which 42 stations are on the High Plains, the West Texas Mesonet with 118 stations, the Kansas Mesonet with 60 stations, the Nebraska Mesonet with 68 stations, the Oklahoma Mesonet with 120 stations, and the South Dakota Mesonet with 29 stations. The High Plains Regional Climate Center (HPRCC) hosts multiple data sources from several states, including the Automated Weather Data Network (AWDN) with meteorological data from Colorado (74 stations), Kansas (55 stations), Montana (6 stations), North Dakota (68 stations), Nebraska (57 stations), and Wyoming (10 stations). Weather data and reference ET are available on a daily, and in some cases hourly, basis on the web sites of the various networks. Many networks also include estimates of crop coefficients and daily crop water use for crops commonly grown in the region. Several states also include water balance-based irrigation scheduling software that growers can use to estimate water use and irrigation requirements for each of their fields. In 
several states, ET data are now accessible through smart phone irrigation scheduling applications (e.g., the WISE system in Colorado, http://wise.colostate.edu/).

Despite the existence of weather station networks, fewer than $30 \%$ of irrigators nationwide use on-farm water management practices, such as weather network data, soil and plant water status sensors, or commercial irrigation scheduling services (USDA-NASS, 2019a). Adoption of these practices is similarly small in the Great Plains. Marek et al. (2010) described reasons for the low adoption rates of irrigation scheduling tools, which included system flaws, obsolescence of computer platforms, and lack of long-term political and funding support. Regionally, however, efforts continue to make it easier for farmers to use these data. Examples include Colorado's Wise Irrigation Scheduler, Kansas' KanSched program, The Diem Dashboard for Irrigation Efficiency Management developed for the Texas High Plains cotton industry, iCrop, which is optimized for Kansas (OgallalaWater, 2019), Nebraska's CornSoyWater (Han, 2016), North Dakota's Web-Based Irrigation Scheduler (Scherer and Morlock, 2008), and an online tool in South Dakota (Oswald and Werner, 2009). Industry is also working to address farmers' ability to manage and use irrigation scheduling data, as evidenced by hardware and software packages for irrigation management available from all center-pivot system manufacturers in the U.S. (Colaizzi and O'Shaughnessy, 2018).

\section{Future Perspectives \\ IRRIGATION TECHNOLOGY FOR IMPROVING ProduCTIVITY AND EFFICIENCY}

Howell (2006b) summarized the challenges of increasing CWP to sustain profitable irrigated agriculture. Pressurized irrigation systems, predominantly center pivots, are already mature technologies that are highly adopted, and continued conversion of surface-irrigated land to center-pivot and drip application systems is likely. Irrigation scheduling, to meet the needs of the crop without water loss to over-irrigation, may be just as important as the choice of application technology, and farmers are aware of this. From 2013 to 2018, the percentage of irrigators using some kind of on-farm water management practice grew from $20 \%$ to $30 \%$ (USDANASS, 2013, 2019a). Further gains can be made by precision deficit irrigation that mildly stresses a crop during non-critical growth stages without large yield reductions (Comas et al., 2019; Trout and DeJonge, 2017). Although the information provided by ET weather station networks allows farmers to make appropriate application decisions for full irrigation, it cannot guarantee success with deficit irrigation because of cumulative differences between estimated and actual ET that can leave a crop too short of water, particularly on soils with low available water holding capacity. In an effort to make precision deficit irrigation feasible for producers, automatic irrigation scheduling and control systems that use real-time soil water and crop sensing have been the subject of research at both Bushland and Lubbock, Texas, since the early 1990s (Evett et al., 1996; Wanjura et al., 1992). Automated drip irrigation of corn was shown to provide well-regulated deficit irrigation and to increase CWP (Evett et al., 2002).

Automatic irrigation systems based on plant temperature sensing have been implemented for both SDI (Evett et al., 2000a, 2002) and center-pivot irrigation (Evett et al., 2006; Peters and Evett, 2008; O'Shaughnessy and Evett, 2010a). These systems were shown to improve yields and CWP compared with scheduling based on neutron probes and the soil water balance, which itself is superior to scheduling based only on reference ET estimates from weather station network data and estimated crop coefficients. Evett et al. (2013) analyzed the results from 83 treatment years of automatic deficit irrigation of sorghum based on plant temperatures compared with dryland and full irrigation based on neutron probe readings (fig. 8). Automated deficit treatments in the range of $50 \%$ to $80 \%$ of full irrigation produced yields comparable to or exceeding those of full irrigation, thus producing greater crop water productivity (fig. 8a). Similar results were obtained with corn under automated SDI (Evett et al., 2000a). Because corn is sensitive to stress during pollination and silking, the automated system could maintain corn yields when irrigation based on soil water sensing was not responsive enough to prevent yield loss due to hot, dry winds during the reproductive period. Considerable research in Colorado has focused on alternative water stress indices that are simpler and require less instrumentation. These studies have involved inter-comparisons between indices and comparisons of indices with transpiration and sap flow measurements (DeJonge et al., 2015; Han et al., 2018; Kullberg et
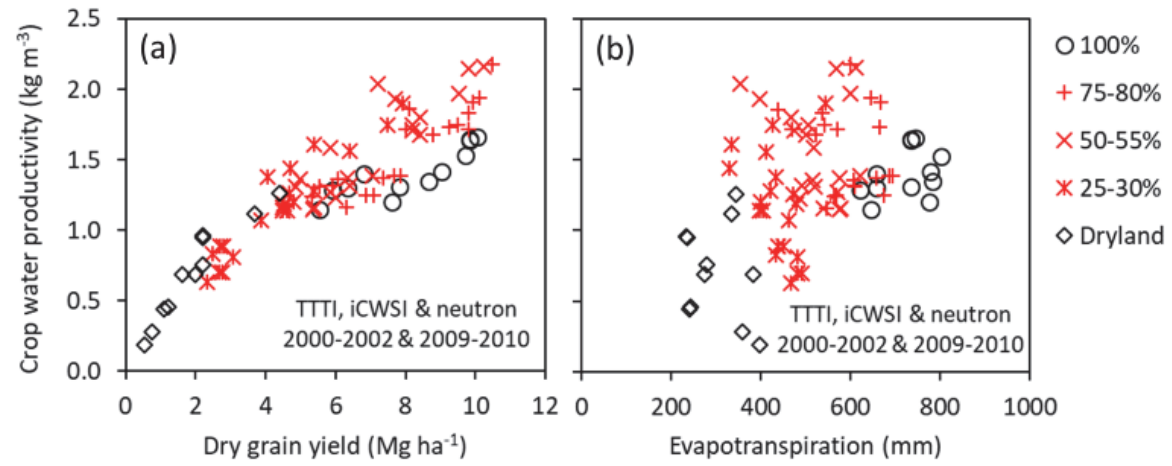

Figure 8. (a) Comparison of crop water productivity (a) versus dry grain yield and (b) versus evapotranspiration (i.e., water used). Data are for sorghum managed with no irrigation (dryland), with automated deficit irrigation, and with full irrigation (100\%) based on neutron probe readings. The time-temperature threshold index (TTTI) and the integrated crop water stress index (iCWSI) were the two algorithms used for automated deficit irrigation (Evett et al., 2013). 
al., 2017; Taghvaeian et al., 2014a, 2014b). Unfortunately, although strong correlations have been shown, these alternative indices have not yet been used to guide irrigation scheduling, so the utility of the indices is unknown.

Variable-rate irrigation (VRI) is another way to increase CWP because it places water where it is can be effectively used by the crop and avoids placing water where it will not be helpful. Research on VRI began at several locations in the U.S. in the 1990s (Evans et al., 2006). In the Great Plains, it began in 1992 at Fort Collins, Colorado (Fraise et al., 1992), in 1991 at Halfway, Texas (Bordovsky, 1991), circa 2000 at Sidney, Montana, and in 1995 for drip irrigation zone control at Bushland, Texas (Evett et al., 1996). Today, there is considerable interest in the use of VRI for improving irrigation management. The paradigm for VRI is to optimize irrigation scheduling with respect to the within-field spatio-temporal variability of crop water needs. This variability can be driven by differences in soil properties, field topography, crop management practices, crop ET, abiotic and biotic stresses, and other factors. Variable watering rates can be applied using mechanical-move irrigation systems outfitted with computerized speed control or more extensive hardware for zone control as well as speed control (Kranz et al., 2012). VRI packages with zone control, capable of precision water delivery (Dukes and Perry, 2006, Han et al., 2009; Chávez et al., 2010; O'Shaughnessy et al., 2013a), are commercially available. VRI research in Nebraska on large fields (the size of commercial farms) has managed irrigation with a remotesensing-based model using satellite imagery (Barker et al., 2018) and unmanned aircraft imagery (Woldt et al., 2018). Lo et al. (2016) estimated that, for most center-pivot irrigation systems for corn and soybean production in Nebraska, it would be difficult to justify investing in zone control VRI based only on the cost savings from reduced pumping. However, they did not include analysis of other potential benefits, such as increased yield, reduced fertilizer use, and avoidance zones (i.e., being able to stop chemigation or irrigation on features such as waterways, ponds, rock outcrops, drainage ditches, canals, etc.). A recent review of VRI research by O'Shaughnessy et al. (2019) has a somewhat more optimistic outlook.

Advances in precision irrigation management using VRI systems have included the integration of wireless sensor network systems for plant canopy sensing (temperature and reflectance) (O'Shaughnessy et al., 2010b) and for soil water sensing (Vellidis et al., 2008) and algorithms using data from sensor networks for irrigation control (Evett et al., 2014; Kim et al., 2008; Hedley and Yule, 2009; O'Shaughnessy et al., 2013b). Sensor network systems deployed on moving irrigation systems or established as static sensors in the field enable the development of dynamic irrigation prescription maps (O'Shaughnessy et al., 2012, 2015), which are essential for responding to the changing spatial variability of plant-available water throughout the growing season. Advances in the reliability and affordability of wireless data transmission (Evett et al., 2018), above the plant canopy and underground (Dong et al., 2013; Salam et al., 2019), will facilitate precision irrigation management. The efficacy of sensor-based irrigation is now well established as a means to apply well-regulated and safe deficit irrigation and thus increase the CWP (fig. 8) and yield as compared with current practices (O'Shaughnessy et al., 2015, 2016). Fully implemented systems are still in commercial development through public-private partnerships, although some system components have been thoroughly tested (e.g., Colaizzi et al., 2018; Schwartz et al., 2016) and are now available commercially (e.g., SAP-IP IRT wireless infrared thermometer, Dynamax, Inc., Houston, Tex.; and TDR-315H and TDR-310H true TDR soil water sensors as well as a wireless node and gateway system with cloud data storage, Acclima, Inc., Meridian, Ida.). Scheduling irrigation in direct response to plant and soil sensing may well be part of the next wave of improvements in overall CWP in the Great Plains and beyond.

Remote sensing technologies also provide an opportunity to quantify crop canopy stress and crop water use. A system developed by USDA-ARS and NASA researchers can provide daily ET with resolutions as fine as $30 \mathrm{~m}$ (Anderson and Kustas, 2008, Anderson et al., 2018). Early work in Colorado correlated crop coefficients to vegetation indices from proximal sensing (Bausch and Neale, 1987) and satellite imagery (Neale et al., 1990). This relationship was updated for the High Plains by Kamble et al. (2013) and Campos et al. (2017). Fine-resolution remote sensing data are now integrated into programs to simulate crop development (phenology) over large Great Plains areas and to follow regional crop rotations (Kipka et al., 2015; McMaster et al., 2013, 2014). Ongoing research in Nebraska is using this remotesensing-based approach to estimate crop yield and CWP as well as ET (Campos et al., 2018). As VRI prescription mapping software becomes more capable of using aerial imagery, satellite imagery, and other georeferenced data, the use of $30 \mathrm{~m}$ ET data from satellite systems is becoming feasible and only waits for the widespread availability of those data.

\section{Changes in Climate, Water Availability, IRRIGATED AREA, AND POLICY}

The previous discussion of current perspectives on irrigation in the Great Plains largely focused on aquifer depletion, along with changes in available groundwater and surface water resources. More recently, the impact of climate change on crop water demand has also shaped discussion of present and future scenarios. However, improved irrigation technology, crop cultivars, and regional and local water policy are interrelated with aquifer depletion and climate change, and this interrelation is becoming increasingly recognized. We discuss each of these aspects in the following sections.

\section{Climate Change}

Changes in both climate and aquifer storage will affect future irrigated area and will likely affect public policy. Recent studies reflect how climate change effects will vary by latitude throughout the Great Plains (Tebaldi et al., 2006). Air temperatures are expected to increase throughout the Great Plains, particularly in the U.S. central Great Plains (fig. 9b), and precipitation is expected to increase in the northern Great Plains but decrease in the central and southern Great Plains (fig. 9a). Heatwave duration is expected to increase by 14 days throughout the region and by 21 days in 
(a)

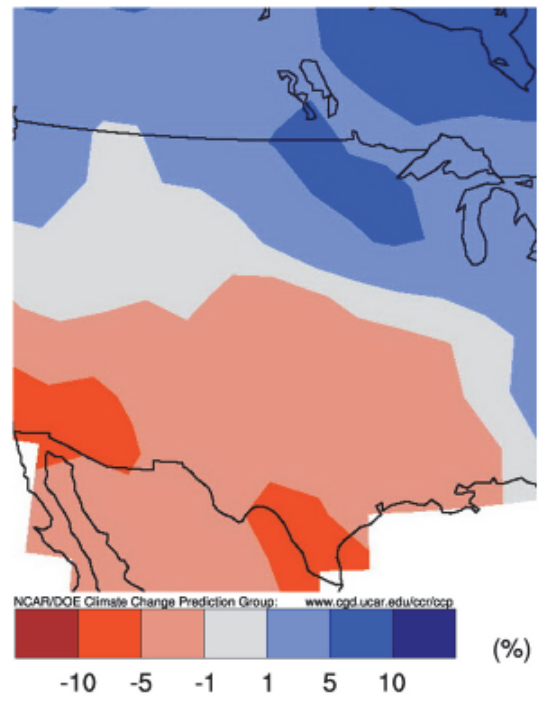

(b)

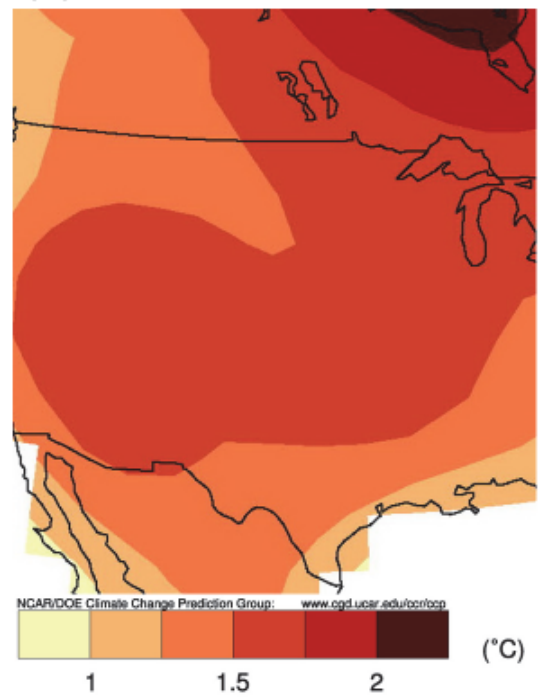

Figure 9. Climate change projections for 1990-2030 for (a) precipitation and (b) surface air temperature (source: Tebaldi et al., 2006).

the central Great Plains, and the growing season is expected to increase by 5 to 10 days (Tebaldi et al., 2006). Depending on crop and latitude, irrigation water requirements will either increase or remain relatively static, but in large areas irrigation water requirements are expected to increase. Increases in water availability, temperature, and growing season may improve the outlook for irrigation in the northern Great Plains. Awal and Fares (2018) assessed climate change impacts on crop water requirements in the 2020s, 2050s, and 2090s in the Texas High Plains. Three climate change scenarios (higher, medium, and lower greenhouse gas emissions) all indicated that temperature and evaporative demand (reference ET) would increase and precipitation would decrease in the region. The increases in gross irrigation requirement for full irrigation were projected to be $2.1 \%$ to $3.8 \%$ in the $2020 \mathrm{~s}, 6.2 \%$ to $9.3 \%$ in the $2050 \mathrm{~s}$, and $6.8 \%$ to $19.5 \%$ in the 2090s. The crops studied were corn, cotton, sorghum, and winter wheat. In contrast, a study of winter wheat production in the northern part of the Colorado High Plains projected mostly positive effects from three climate change scenarios that ranged from mild to severe (RCP 8.5; RCP stands for Representative Concentration Pathway, which is a greenhouse gas concentration trajectory; IPCC, 2013). Elsayed et al. (2018) projected temperature increases under all scenarios, but also projected increases in precipitation of $10 \%$ to $15 \%$ in January through March. Due to the enhanced precipitation, both biomass and yield of fully irrigated winter wheat were projected to increase under RCP 8.5 in 2050 and 2080 , with yield projected to increase by $7 \%$ to $13 \%$. For wheat irrigated at $40 \%$ of full ET, increases in yield under RCP 8.5 were similar in trend to those projected for fully irrigated wheat. Increased winter temperatures shortened the wheat growing season, while greater $\mathrm{CO}_{2}$ concentrations plus increased precipitation combined to increase yields. In short, for the northern Great Plains, there may be increases in CWP due to the synergistic effects of increased winter precipitation, temperature, and $\mathrm{CO}_{2}$ concentration, as well as an opportunity to profitably practice deficit irrigation strate- gies that would decrease water demand. These findings are in line with other climate change studies that projected increased evaporative demand throughout the Great Plains but much greater increases in the southern portions, including western Texas, western Kansas, and southeastern Colorado (McDonald and Girvetz, 2013), and projecting increasing precipitation and overall effective reduction in irrigation water demand in the northern Great Plains (northeastern Colorado, Nebraska, and further north) (Elliott et al., 2014). In California's San Joaquin Valley, climate change is expected to shorten growing periods such that seasonal water demand is not much increased by rising temperatures (Hopmans and Mauer, 2007). Similar phenological phenomena may result from climate change on the Great Plains, but farmers may adapt by growing higher-yielding longer-season varieties where growing seasons are lengthened. This could increase irrigation requirements.

In Nebraska, a decreasing trend in ET has been observed over the past century (Irmak et al., 2012), and soil moisture decline was identified as a limiting factor for both ET and groundwater recharge (Munoz-Arriola et al., 2014). Expected intensification of the water cycle behavior (both wetting events and consecutive dry days) is likely to result in increased runoff and a need for runoff storage (reservoirs or groundwater recharge) to preserve excess precipitation for later irrigation needs (Munoz-Arriola et al., 2014). Ou et al. (2018) modeled the influence of climate change in the Republican River basin of Nebraska, Kansas, and Colorado. They concluded that "(1) water stress in the irrigation season will be exaggerated due to increased irrigation water demands; (2) recharge will increase in the non-irrigation season; (3) groundwater levels will decline more in areas with declining trends in the baseline; and (4) baseflow will increase because of increased groundwater recharge in the Republican River valley." In a long-term analysis of ET across the Great Plains, Kukal et al. (2017) found that, in most counties, corn and soybean have had increasing trends in crop ET, while trends in reference ET are decreasing. Kukal 
and Irmak (2018) analyzed historical crop yield and meteorological data across the Great Plains and found the trend in temperature change to be beneficial for corn but detrimental for sorghum and soybean; the trend in observed precipitation change was found to be beneficial for all three crops. Efforts have also been made to characterize actual irrigation patterns in a way that can be incorporated into land surface modeling and operational forecast models (Gibson et al., 2017).

\section{Water Availability: Aquifer Storage and Surface Water Supplies}

In parts of Colorado, Nebraska, North and South Dakota, Wyoming, and Kansas, rivers are important for irrigation water supply. Most of these river systems are over-allocated. Irrigation in Montana is mainly from reservoirs and diversions from the Missouri and Yellowstone Rivers and their tributaries. In North and South Dakota, irrigation is mainly from reservoirs built along the Missouri River and its tributaries (ECONorthwest, 2008). In addition to state water laws, interstate agreements and disagreements are key factors in surface and subsurface water availability for irrigated agriculture. For example, in 1942, the Republican River Compact was negotiated by the states of Colorado, Kansas, and Nebraska and a representative of the president of the U.S. with approval by Congress in 1943. The compact was intended to: (1) provide for equitable division of Republican River basin waters, (2) eliminate causes of controversy and promote interstate comity, and (3) promote efficient use of water and control of floods through joint action by the states and the U.S. (www.republicanrivercompact.org/). Unfortunately, this was only the beginning of a long series of disputes among the three states over equitable division of the waters, disputes that were only settled in 2002 (http://republicanriver.org/). Another important example is the suit brought in 1934 by Nebraska against Wyoming and Colorado over rights to North Platte River water. That suit was only settled in 1945 in an opinion by Justice Douglas for the U.S. Supreme Court that limited storage and diversion of water in Colorado and Wyoming (325 U.S. 589, 66 S. Ct. 1, 89 L. Ed. 1815, 1945 U.S. LEXIS 2620).

River systems do not supply substantial irrigation water in the Texas and Oklahoma Panhandles, where the High Plains aquifer is practically the only irrigation water source. In much of western Kansas, eastern Colorado, and Nebraska, the High Plains aquifer is also the major source of irrigation water. Irrigation withdrawals greatly exceed aquifer recharge in the Texas and Oklahoma Panhandles, Kansas, eastern Colorado, and western Nebraska.
In the eight states overlying the High Plains aquifer, the overall aquifer depletion by volume between 1980 and 2009 was $11 \%$ (table 2), but depletion rates varied greatly among the states (McGuire et al., 2012). The smallest depletion rates were in South Dakota $(<1 \%)$ and Nebraska $(7 \%)$. The former overlies $2.8 \%$ of the aquifer area, but the latter overlies $36.9 \%$ of the aquifer area, the most of any state. The largest depletion rates were in Kansas (19\%), New Mexico (40\%), and Colorado (33\%). Texas overlies the second largest area of the aquifer, at $20.8 \%$, and its High Plains region relies entirely on the aquifer for irrigation water, so the $15 \%$ depletion rate there is affecting the irrigated area and irrigation methods and management. In the more southern Great Plains states, the irrigation water supply has decreased somewhat in step with water table and well yield declines since circa 1950. At current rates of depletion, the Southern High Plains stands to lose $35 \%$ of its irrigated land surface in the next 20 to 30 years (Scanlon et al., 2012). Between 1980 and 2007, the mean depletion was $10 \mathrm{~m}$ in Kansas and $11 \mathrm{~m}$ in Texas (Scanlon et al., 2012), but much greater in some areas. Chloride mass balance studies have shown recharge to be greatest (25 to $211 \mathrm{~mm} \mathrm{year}^{-1}$ ) in Nebraska and northeast Colorado and least $\left(<2\right.$ to $25 \mathrm{~mm}$ year $\left.^{-1}\right)$ in southwest Kansas, southeast Colorado, and the Oklahoma and Texas Panhandles (Scanlon et al., 2012).

Steward et al. (2013) studied groundwater supplies, current irrigated production and pumping rates, and future scenarios in Kansas. They stated that aquifer depletion had reached $30 \%$ and could increase to $69 \%$ over the following 50 years if current trends continued. They evaluated scenarios that involved reduction of pumping by $20 \%$ to $80 \%$ and concluded that reducing pumping by $80 \%$ from current rates could enable production from irrigation into the indefinite future, particularly if CWP continued to increase. As aquifers decline, well yields decline due to the decreased saturated thickness. The peak of groundwater depletion (pumping) rates was likely reached in 1999 in the Texas High Plains, 2002 in eastern New Mexico 2010 in Kansas, and 2012 in the Oklahoma Panhandle. For the High Plains aquifer as a whole, the peak depletion rate likely occurred in 2006 (Steward and Allen, 2016). The same authors projected peak depletion to occur in 2023 in eastern Colorado, but not before 2110 in Nebraska, South Dakota, and Wyoming. These projections inform ongoing policy discussions in Kansas and neighboring states.

Another trend is the dwindling supply of water available for delivery by surface water projects in Nebraska and parts of Colorado and Kansas. In 2014, Nebraska irrigators along

Table 2. Summary of overall water supply in the High Plains aquifer and how much was depleted from 1980 to 2009 (McGuire et al., 2012).

\begin{tabular}{cccccc}
\hline State & $\begin{array}{c}\text { Percentage of Total } \\
\text { Aquifer Area } \\
(\%)\end{array}$ & $\begin{array}{c}\text { Volume of Water } \\
\text { in Storage in } 1980 \\
\left(10^{9} \mathrm{~m}^{3}\right)\end{array}$ & $\begin{array}{c}\text { Portion of Aquifer Water } \\
\text { in Each State in 1980 } \\
(\%)\end{array}$ & $\begin{array}{c}\text { Change in Storage } \\
\text { from 1980 to 2009 } \\
\left(10^{9} \mathrm{~m}^{3}\right)\end{array}$ & $\begin{array}{c}\text { 2009 Aquifer Depletion } \\
\text { Relative to 1980 Storage } \\
(\%)\end{array}$ \\
\hline Colorado & 7.6 & 97.3 & 3.5 & -32.4 & 33 \\
Kansas & 17.7 & 259.4 & 14.2 & -48.6 & 19 \\
Nebraska & 36.9 & 1,727 & 62.3 & -122 & 7 \\
New Mexico & 5.3 & 40.5 & 1.5 & -16.2 & 40 \\
Oklahoma & 4.3 & 89.2 & 3.2 & -8.1 & 0 \\
South Dakota & 2.8 & 48.6 & 1.8 & 0 & 0 \\
Texas & 20.8 & 316.2 & 11.4 & -48.7 & 15 \\
Wyoming & 4.6 & 56.8 & 2.1 & -8.2 & 14 \\
\hline Total & 100 & 2,635 & 100 & -284.2 & 11 \\
\hline
\end{tabular}


the Republican River expected to receive between 0 and $64 \mathrm{~mm}$ of irrigation water. In the Mirage Flats Irrigation District in the Nebraska Panhandle, the 2014 delivery was set at $64 \mathrm{~mm}$. These two examples are indicative of the increased level of competition for available water supplies and the diminishing supply of surface water available for irrigation. In eastern Colorado, the water supplies are groundwater and surface water emanating from snowmelt in the Rocky Mountains. Over-allocation of water supplies, growing urban populations and water needs, and the desire to improve riparian areas will result in a decrease in water available for irrigation. The 2010 Statewide Water Supply Initiative report estimated that lack of water availability on the Colorado eastern plains will result in a reduction in the irrigated area of 130,000 to 180,000 ha by 2050 , more than $20 \%$ of the currently irrigated area (CWCB, 2010). In the past, water deficits in the east were compensated by trans-basin diversions from the western slope. However, the realization that the Colorado River basin is also over-allocated has likely halted any future trans-basin diversions.

\section{Irrigated Area and Policy}

The irrigated area in the ten Great Plains states is influenced by the water rights structure in each state and by public policy built around those rights. In some states, water rights are correlative, meaning that the land owner has right to the water underneath the land; in other states, the prior appropriations doctrine prioritizes the rights of those who appropriated water earlier in time. Riparian rights add to the regulatory framework such that no simple discussion applies to all states. Here we focus on water policy and irrigated area in the four Great Plains states with the largest irrigated areas.

In Colorado, from 1998 to 2018, the irrigated area declined by $16 \%$ to 995,000 ha. Under Colorado water law, much of the groundwater, including some portions of the High Plains aquifer, is considered hydraulically connected to surface water and thus is regulated under the same prior appropriation rules used for surface water. Under these rules, more than 1000 groundwater wells have been shut down in response to declining river flows. Growers who wish to continue pumping groundwater often must compensate for any impacts that their pumping might have on river flows through an "augmentation" plan in which they recharge the groundwater from unclaimed surface water or otherwise replace projected river flow depletions. Current research studies and policy debates are focused on ways to use the groundwater conjunctively with surface waters to maximize flexibility and benefits.

Because Colorado is a headwater state, many irrigators, including some downstream users in Nebraska and Kansas, depend on return flows from upstream irrigation. Non-consumptive irrigation water is assumed to return to the rivers and be used downstream. Thus, water rights in Colorado for surface and hydraulically connected groundwater are based on consumptive use (evapotranspiration), rather than diversions or pumped amounts. For this reason, improvements in irrigation efficiency will not necessarily result in more water available for irrigated agriculture in the relevant parts of Colorado. This greatly reduces the technical options available to sustain current production levels. Current research on regu- lated deficit irrigation and genetically improved varieties is seeking ways to sustain productivity with reduced consumptive use. The Colorado Water Plan (CWCB, 2015) has objectives to increase the agricultural economy even though some irrigated areas go out of production as municipal water demands increase; the plan aims to achieve this by promoting voluntary methods of non-permanent transfer of water from agricultural to municipal and industrial users, and by attaining 400,000 acre-feet of water storage to enable better management of water resources.

In Kansas, the irrigated area was $\sim 1.15$ million ha in 2013, having remained fairly steady since 1998 while irrigation methods changed greatly, but the irrigated area then declined by $16 \%$ to 966,000 ha in 2018 . Rogers and Lamm (2012) summarized irrigation trends in Kansas, where the sprinkler and furrow-irrigated land areas were approximately equal in 1990. Beginning in about 1993, there was a rapid conversion, lasting until about 2000, during which approximately 400,000 ha of furrow-irrigated land was converted to center-pivot sprinkler irrigation. This conversion of furrow irrigation to center-pivot sprinklers or SDI continues. The remaining furrow-irrigated area is estimated to be only 70,000 ha. SDI is used on less than $1 \%$ of the total irrigated land area in Kansas but is increasing at a rate of approximately 2000 ha year ${ }^{-1}$. As more producers gain experience with SDI, it is anticipated that this method will see increased use, particularly in areas with the greatest decreases in groundwater well capacity. With declining water resources, groundwater diversions in Kansas are gradually decreasing at a rate of approximately 56 million $\mathrm{m}^{3}$ year-1 and are currently at a total of 37 billion $\mathrm{m}^{3}$ year-1. Average irrigation applications are decreasing by approximately $5 \mathrm{~mm}$ year ${ }^{-1}$. Recent changes in Kansas water laws are designed to allow more flexibility in managing water at the local level and at the producer level. A group of producers can voluntarily develop a Local Enhanced Management Area (LEMA) to help restrict groundwater pumping with the goal of conserving water and improving equitable sharing of the limited water resources. In 2018, a districtwide LEMA was formed in northwest Kansas Groundwater District 4, which covers nearly 1.26 million ha of which 0.16 million ha are irrigated. Allocated water in this LEMA is reduced by $25 \%$ to $37.5 \%$ from permitted water rights. Nonetheless, average applied amounts are anticipated to be affected to a much lesser extent, largely due to the multi-year flexible water use allocations, which will allow individual Kansas producers to balance their water use across inter-annually variable climate conditions.

In Nebraska, there was a fairly steady increase in irrigated area to approximately 3.36 million ha in 2013, even though the number of active wells had not increased greatly (NDR, 2018), followed by a decline to 3.1 million ha in 2018 (table 1). The decline in depth of water applied was likely due to improvements in irrigation efficiency, as pressurized systems have been installed on former gravity-irrigated land. The percentage of area irrigated with center-pivot systems $(88 \%)$ has also increased, as has the number of such systems powered by electricity ( $\sim 55 \%$ presently). Aquifer levels in Nebraska have fallen by less than $0.3 \mathrm{~m}$ on average over the last 60 years (Scanlon et al., 2012), and the small water table 
decline is accounted for by recharge nearly keeping up with overall withdrawals. The greater recharge is due to both less evaporative demand than in more southerly states and greater recharge, primarily in the permeable soils in the $\mathrm{Ne}$ braska Sand Hills, as well as water resource conservation efforts.

In 1972, Nebraska established a system of natural resource districts (NRDs) to consolidate smaller districts into a more efficient, comprehensive system while maintaining local control through a locally elected board for each NRD (Bleed and Babbitt, 2015). The NRD system (fig. 10), with boundaries determined primarily by watersheds, has been successful in many ways and has been an example of water governance for other states and countries. Local NRDs determine whether or not to institute allocations for groundwater pumping, and the size of any allocations. The NRD decisions are based primarily on the need to minimize stream depletion from groundwater pumping. Minimum streamflows are required for endangered and threatened species and for interstate water compacts. The Upper Republican NRD initiated an allocation of $51 \mathrm{~cm}$ (20 in) per year in 1978-1979 (https://www.urnrd.org/about), becoming the first government entity in Nebraska to regulate groundwater use. This allocation was slowly decreased over time to the current allocation of $33 \mathrm{~cm}$ (13 in.) per year. Allocations in this and other NRDs have reduced the rate of water table decline in the High Plains aquifer. Reducing allocations slowly has given producers time to adapt and has fostered innovation in best management practices, improving AE and IWP. While many of these reductions in pumping have not reduced consumptive use, the adoption of conservation strategies is a positive outcome. As allocations continue to decline, maximum yields will no longer be possible, consumptive use will necessarily be reduced, and deficit irrigation strategies to maximize CWP will become critical.
The number of NRDs that have implemented integrated water management plans (IWMPs) has steadily increased (fig. 10). These plans usually include rules pertaining to water meters, yearly water allocation, and limitations on new irrigated areas. Even NRDs in which the available water is not fully allocated are trending toward voluntary implementation of IWMPs. In the far western part of Nebraska, pumping restrictions mean that no additional area can be irrigated, and a water allocation limits water withdrawals over periods of 3 to 5 years. These restrictions are gradually moving farther east in response to the development of irrigation wells in areas that traditionally have supported only rainfed agriculture. In 2012, the Lower Elkhorn NRD in northeast Nebraska placed a moratorium on new irrigated acres; in 2013, the district implemented a water allocation plan that required the installation of water meters on more than 200 irrigation wells.

In the Texas High Plains, the irrigated area reached a peak of nearly 2.43 million ha in 1974 but declined to 1.65 million ha by 2018 , largely due to decreased availability of water from the Ogallala aquifer (fig. 11b). The area irrigated by gravity steadily declined after 1974 as the sprinkler-irrigated area increased and the total irrigated area declined. By 2008, less than 364,000 ha $(<19 \%)$ were irrigated by gravity. Sprinklers were mainly center pivots, although early systems included hand-move lines, side-roll systems, and the TriMatic variant of side roll (Rolland, 1982). Microirrigation (mainly SDI) has been used in the Trans Pecos and Southern High Plains areas since circa 1984, mainly for cotton production (Henggeler, 1995), but adoption began to increase more rapidly after 2000 . The sprinkler-irrigated area increased to $89 \%$ by 2013 but declined to $80 \%$ by 2018 , mostly due to the decline in irrigated area in the Texas High Plains (fig. 11b) and concurrent increase in SDI in the region to $6.6 \%$ of the irrigated area by 2018 (USDA-NASS, 2019a).

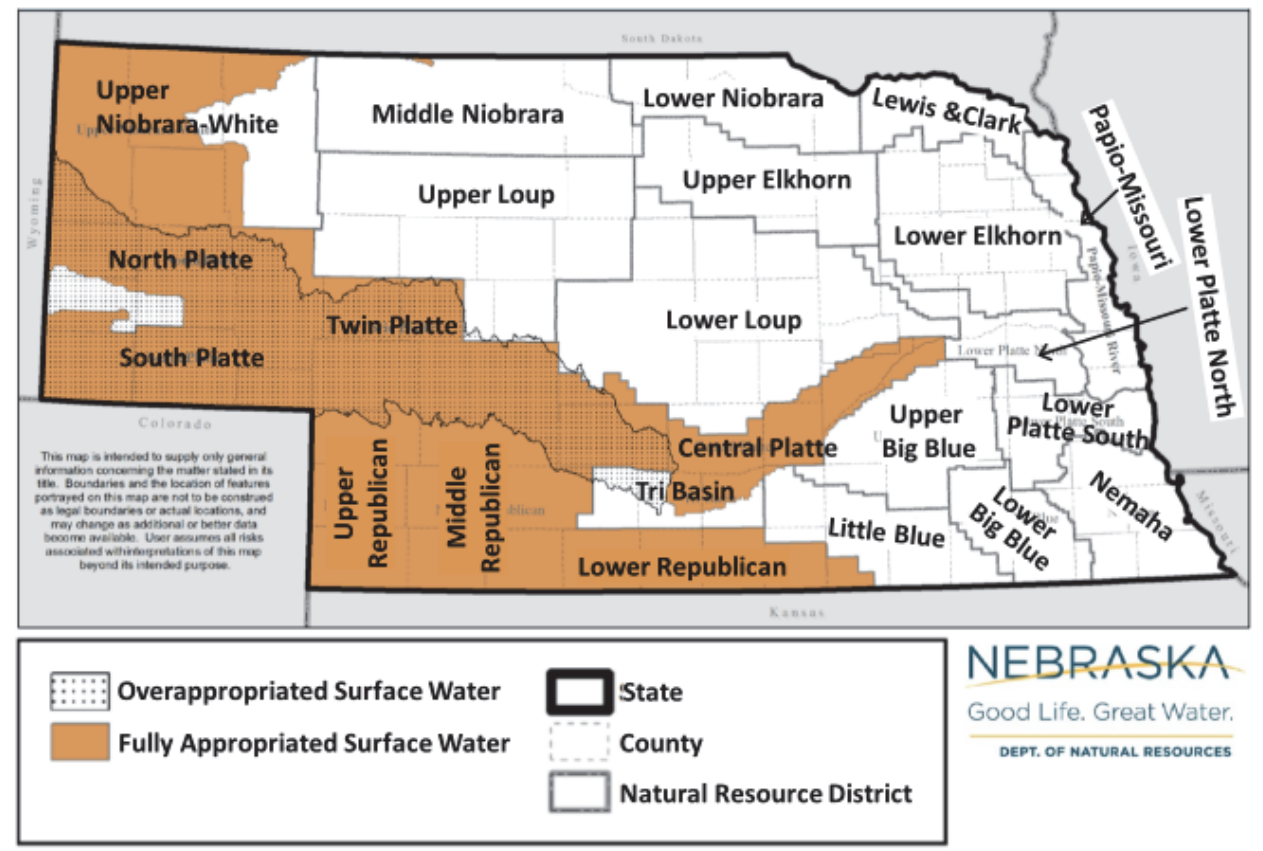

Figure 10. Nebraska natural resource districts (NRDs) that have been declared over-appropriated, fully appropriated, or not fully appropriated (after https://dnr.nebraska.gov/sites/dnr.nebraska.gov/files/doc/water-planning/statewide/FAB/2018AnnualReport/20171229_FAB_Final.pdf). 

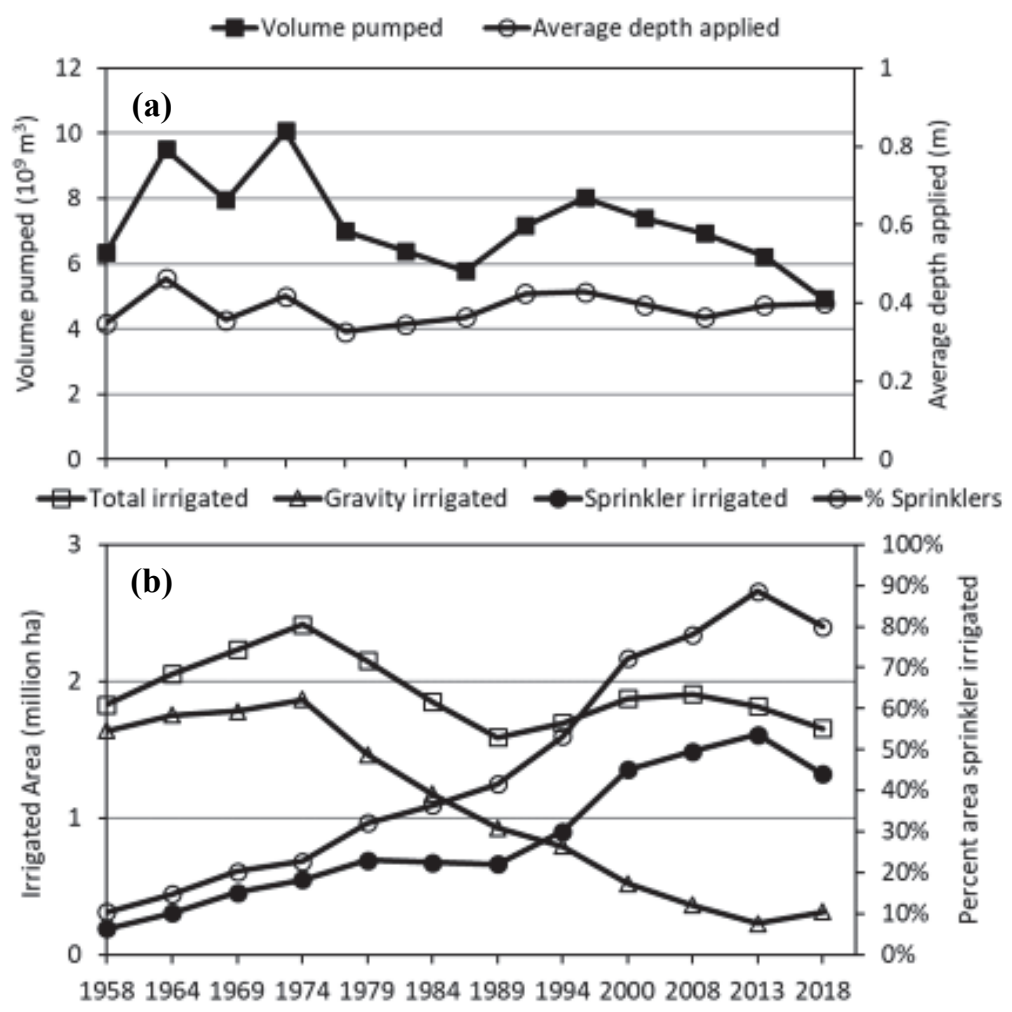

Figure 11. (a) Volume pumped and average depth pumped in the Texas High Plains (TWDB, 2001, 2011, 2012; USDA-NASS, 2013, 2019a) and (b) irrigated area, area irrigated by gravity, area irrigated by sprinkler, and percentage of area irrigated by sprinkler in the Texas High Plains (TWDB, 2001, 2011, 2012; USDA-NASS, 2008, 2013, 2019a).

Sprinkler adoption was most rapid after 1989, when total irrigated area began to increase again after a lull due to increases in energy prices earlier in the 1980s.

The volume of water pumped from the aquifer for irrigation in the Texas High Plains followed a somewhat similar trend as irrigated area, although with a decreasing trend after 2000 in volume pumped (fig. 11a). Because well yields have declined since irrigation development began, the number of wells more than doubled, from 48,160 in 1958 to 101,299 by 2000, to maintain the volume of water pumped (TWDB, 2001). The average amount pumped per unit irrigated area (i.e., before application losses) depends on numerous factors, such as rainfall and climate, energy costs, crops grown, and irrigation technology and management. However, although the irrigation volume pumped has steadily declined since 2000 , the average depth applied has decreased only slightly and not steadily between 2000 and 2018. The data in figure 11 for 2013 and 2018 are drawn from the USDANASS and may not be congruent with the earlier data drawn from Texas Water Development Board (TWDB) reports.

The trend of decreasing volume of water pumped for irrigation in the Texas High Plains will no doubt continue during this century due to declines in available groundwater, increased pumping depths, and regulations that will limit pumping. Evidence for this is that although the mean depth of irrigation applied remained fairly steady from 2008 to 2018 , the irrigated area declined by $22 \%$ over the same period (table 1). Texas recently required that all groundwater conservation districts establish desired future conditions (DFCs) of groundwater availability (Mace et al., 2006). To meet this mandate, districts in the Texas High Plains and elsewhere have mandated metering of irrigation wells and have become more aggressive in promoting or requiring water conservation practices (TWDB, 2012). Even if DFCs are achieved, regional groundwater planning groups project that the Ogallala aquifer will yield only $50 \%$ to $60 \%$ of its 2010 capacity by 2060 (TWDB, 2012). By 2060, municipal water demand at the state level is projected to increase by $11 \%$ of its value in 2010, becoming slightly larger than irrigation demand (Combs, 2014) and putting more pressure on groundwater conservation districts and producers to conserve water. Hence, the loss of irrigated area will be inevitable (Scanlon et al., 2012), but increases in crop water productivity will play an important role in sustaining economically viable production.

\section{Crops Grown}

Changing economics and genetics are influencing the kinds of crops grown on irrigated land. Corn is currently produced on approximately $50 \%$ of the irrigated land in Kansas; the land in corn has been relatively stable since 2000 at approximately 600,000 ha. Corn yield advances and economics have reduced the irrigated area for wheat and grain sorghum to approximately 275,000 and 75,000 ha, respectively, from the roughly equal division of irrigated area between corn and these two crops in the mid-1980s. Similar trends of increasing corn cultivation and decreasing sorghum and winter wheat cultivation have been observed in Colorado, Texas, and Nebraska. Some of this shift in crops grown is linked to differences in CWP. The winter wheat CWP is at best $\sim 1.1$ to $1.2 \mathrm{Mg} \mathrm{m}^{-3}$ (fig. 5), sorghum CWP is $\sim 1.5$ to $1.7 \mathrm{Mg} \mathrm{m}^{-3}$ for full irrigation and $\sim 2.0 \mathrm{Mg} \mathrm{m}^{-3}$ for carefully controlled 
deficit irrigation (figs. 7 and 8), and corn CWP is $\sim 2 \mathrm{Mg}$ $\mathrm{m}^{-3}$ for full irrigation, increasing to $\sim 2.2 \mathrm{Mg} \mathrm{m}^{-3}$ for well controlled deficit irrigation (Xue et al., 2017), but corn yields are much larger than for either sorghum or wheat. Facing limited water supplies, farmers may choose corn over sorghum and winter wheat, unless corn prices are severely depressed relative to those other crops. Xue et al. (2017) analyzed trends in corn yield and CWP from 1975 to 2013 in the Texas High Plains and nationally. They found steady yield increases of $0.12 \mathrm{Mg} \mathrm{ha}^{-1}$ year $^{-1}$ in both cases. They also found steady decreases in seasonal water use of $4.2 \mathrm{~mm}$ year $^{-1}$ and increases in CWP of $0.023 \mathrm{~kg} \mathrm{~m}^{-3}$ year $^{-1}$. These changes were attributed to improvements in corn hybrid tolerance to drought and other stresses. Irmak et al. (2019) reported lower ET, higher grain yields, and higher CWP for newly developed drought-tolerant corn hybrids compared to standard hybrids at two locations in Nebraska. Climate change is also influencing cropping patterns. The $2{ }^{\circ} \mathrm{C}$ increase in winter temperature over the past 20 years in the Texas High Plains have made winter wheat cultivation riskier because winter wheat is coming out of dormancy much earlier in the late winter and using soil water reserves before heading and grain filling. Warmer temperatures combined with improved cotton genetics and irrigation application methods have resulted in increases in cotton cultivation in the northern Texas High Plains and into the Oklahoma Panhandle and Kansas. The rapid expansion of SDI for cotton cultivation has promoted earlier cotton growth and an effectively longer cotton growing season due to warmer soils under SDI compared with sprinkler irrigation (Colaizzi et al., 2006).

Changing price structures and demands for particular crops will also influence the extent of irrigated lands and the crops grown on them. In Kansas, the land area devoted to irrigated corn production is currently greater than that for any other crop. However, in the Texas Panhandle, corn is being displaced by cotton as both well capacities and corn prices decline, resulting in 344,000 ha planted to cotton in 2018, with approximately half that area irrigated (Ledbetter, 2019). One reason for this change is that cotton production with deficit irrigation is less risky than deficit-irrigated corn; about half of cotton acreage in this region is dryland, whereas almost no corn is produced without irrigation. The irrigated corn area was $>560,000$ ha in 2016 (Xue et al., 2017) but declined to $\sim 317,000$ ha in 2017 and was further reduced by $\sim 20 \%$ in 2018 (USDA-NASS, 2019b). Almas et al. (2006) conducted an economic optimization balancing water availability and extraction costs against crop revenues and projected a steady decline in corn area, an even steeper decline in irrigated wheat area, and further declines in irrigated sorghum area. Cotton was projected to lose the least percentage of area and to still be irrigated in 2061, while alfalfa was projected to gain irrigated area and become the largest irrigated crop by 2061 , largely due to increasing forage demand from the growing dairy industry in eastern New Mexico and the Texas Panhandle. Simplifying assumptions make exact predictions impossible with such economic models, and changes in irrigation technology, crop genetics, and farmer decisions to spread risk were not included in their model.
In the future, local and stakeholder input will continue to be important for groundwater policy, thus engendering significant heterogeneity in policy across the High Plains aquifer (Schoengold and Brozovic, 2018) and the Great Plains in general. Initially less-strict water allocations can have a "signaling impact," encouraging producers to adopt conservation practices even though the allocation is not enough to result in a measurable decrease in profit or yield (Schoengold and Brozovic, 2018). Regardless of local and regional differences in policy, the clear trend is for increased regulation of irrigation water withdrawals across the U.S. Great Plains. In addition to local and state policies, federal policy will have strong impact on crops grown and to some extent on area irrigated due to crop insurance, price supports, and ethanol production policies. As this is written, international trade tensions and tariffs are contributing to depressed prices for corn, cotton, soybeans, and wheat. The current U.S. Farm Bill has strong programs for disaster assistance that somewhat temper the effects of natural disasters linked to climate change, including both flood and drought. Such payments are projected to total $>\$ 1.7$ billion in 2019 (USDA-ERS, 2019).

\section{Future Policy and Partnering}

Policies for water allocations, as well as recommendations for voluntary best management practices, are most effective when informed by an accurate characterization of current practices. Grassini et al. (2011) used a large dataset of commercial fields in central Nebraska and developed a benchmark for corn water productivity. They found that actual water productivity on average was $73 \%$ of the benchmark. Gibson et al. (2018) used nine years of data from approximately 1400 corn and soybean fields in Nebraska to analyze factors affecting irrigation decisions. Seasonal water deficit, crop type, and soil properties only explained half of the variation in field irrigation, indicating that producer behavior, skill level, and the "neighbor effect" have a significant influence. Foster et al. (2019) used a similar data set together with remote sensing data and also found that actual water use was often different from biophysical crop water requirements.

A recent study from the Council for Agricultural Science and Technology (CAST, 2019) addressed aquifer depletion and its impacts on irrigated agricultural productivity in the U.S., including the Great Plains. The policy and institutional changes examined herein are reflected in those proposed in the CAST report. In particular, the Great Plains states have largely settled on a decentralized approach to regulatory control, albeit with strong guidance from state institutions. The prior appropriations doctrine is the rule in some states, whereby junior water users lose rights to water if their withdrawals would damage the rights of senior water users. In other states (e.g., Nebraska, Oklahoma, and Texas), water is considered a correlative right in which the owner of the land has a right to the water underneath it. The CAST report states that "governing access and use of groundwater under the prior appropriation doctrine has not addressed groundwater depletion for at least two primary reasons." The first reason is that, in most places, a requirement of the doctrine is that beneficial use of the water right must be consistent over 
time, which is a disincentive to farmers who might otherwise institute water conservation practices. State laws can address this if they are put in place. The second reason is that the typical governance structures in place do not address conditions in which the aquifer cannot be replenished at anywhere near the rate of depletion, which is the case in the Southern High Plains. Strict application of the prior appropriations doctrine would recognize that overdraft by junior water users will inevitably cause future declines in the water available to senior water users; recognizing that fact would require actions that states and local regulatory districts are loath to adopt. Where correlative rights are the rule, the states have set up regulatory frameworks, such as the groundwater conservation districts in Texas and the NRDs in Nebraska, with variable results so far in decreasing or stopping groundwater depletion. CAST suggests that financial incentives, such as the low-cost loans from the Texas Water Development Board or the cost-share programs of the NRCS, have the most impact in decreasing groundwater depletion where groundwater is the primary resource used for irrigation but may have a negative impact in regions where surface water resources are used and increased efficiencies cause a decrease in recharge.

The North American Great Plains are the world's largest contiguous area where dryland and rainfed farming are done in conjunction with irrigation, and where irrigation management must take into account precipitation patterns. Because of this, and due to the wide range in mean annual precipitation and climate in the Great Plains (fig. 2), lessons learned regarding irrigation in the Great Plains are relevant to irrigation management in semi-arid and subhumid climates around the world. Several examples of global outreach illustrate how important this is becoming. Founded in 2010, the Daugherty Water for Food Global Institute at the University of Nebraska is actively transferring knowledge and technology from the Great Plains nationally, e.g., California (Babbitt et al., 2018), and internationally, e.g., Brazil, India, Rwanda, and Malawi (Banda et al., 2019) (https://waterforfood.nebraska.edu/). Established in 2018, the Irrigation Innovation Consortium operated out of Colorado State University is "a collaborative research effort to accelerate the development and adoption of water and energy efficient irrigation technologies and practices through public-private partnerships" both in the western U.S. and internationally (https://irrigationinnovation.org/). The Consortium has eight founding industry partners and five founding university partners, four of which are in the Great Plains (Colorado State University, Kansas State University, Texas A\&M, and the University of Nebraska-Lincoln). In the Southern Great Plains, the Ogallala Aquifer Program (OAP) was formed in 2003 as a consortium of USDA-ARS laboratories at Bushland and Lubbock, Texas, with Kansas State University, Texas A\&M University, Texas Tech University, and West Texas A\&M University (https://ogallala.tamu.edu/). The OAP consortium partners have research collaborations throughout the Great Plains, the U.S., and globally.

Looking forward, a key concern is that adoption rates of irrigation best management practices remain relatively low; in fact, there may be a greater need for technology transfer than for filling knowledge gaps (research). Barriers to adoption include time, cost relative to return on investment, producer knowledge gaps, technology literacy, and habit. Irrigated systems have become increasingly complex, and partnering with industry for technology development may be a way to maximize impact by incorporating best management practices into user-friendly industry decision support systems (e.g., smart phone apps for irrigation monitoring and control) and into the technology sold by industry to farmers (e.g., soil, plant, and weather sensing systems integrated into VRI systems). The OAP consortium partners have tried to fill some of these technology transfer gaps with major efforts concerning SDI in 2009-2010 (Lamm et al., 2012) and again for center-pivot irrigation in 2017-2018. A discussion of the center-pivot technology transfer effort is provided by Lamm et al. (2019b). Traditional extension efforts of reaching out to producers, crop consultants, and irrigation dealers will continue to be important, but extension's role should increasingly include demonstrations of new, commercially available technologies in field settings. Innovative approaches in extension, such as social media and interactive farm management competitions, e.g., UNL Testing Ag Performance Solutions (UNL-TAPS, https://taps.unl.edu/), and demonstration farms, e.g., Texas Alliance for Water Conservation, https://www.depts.ttu.edu/tawc/), are also making an impact.

\section{Conclusions}

In the Great Plains, soil and water conservation is being achieved in both dryland and irrigated agricultural systems, and increasingly in combinations of these systems. Reduced tillage has increased the retention of crop residues on the surface and reduced the evaporative loss of water, making more water available for plant growth and yield formation in both dryland and irrigated systems. Irrigation application efficiencies have steadily improved due to the move from gravity to pressurized systems, and applied irrigation amounts have declined generally. Efficiency increases have also resulted from the introduction of piped delivery systems, alternate-furrow irrigation, and LEPA and drip irrigation technologies. The ongoing improvements in reduction of evaporative losses in pressurized systems have improved crop water productivity, particularly for SDI. Crop water productivity has also seen steady increases with advances in crop genetics and more drought-tolerant hybrids and varieties. Improved irrigation scheduling methods and technologies have reduced losses of water to unproductive irrigation, runoff, and deep percolation and have also reduced yield loss due to under-irrigation, leading to overall improvements in crop water and nutrient productivities. These trends are expected to continue, as the population of the Great Plains has demonstrated tremendous adaptability in agriculture and irrigation methods and management in the past.

Future advances in irrigation technology are likely to focus more on decision support systems than on irrigation hardware. Sensor-based decision support systems are being refined into commercially viable systems and will include on-board proximal sensors for moving irrigation systems as 
well as aerial imagery and satellite imagery, coupled with knowledge of biophysical systems, artificial intelligence approaches, and embedded computational systems that are linked to irrigation control. These systems, complex on the inside but simple to the user, will often be cloud-based and available as user-friendly apps on smart phones, tablets, and computers. Major irrigation equipment manufacturers are already offering nascent systems with their equipment. Thus, rather than producers being asked to adopt an irrigation management program provided by university or agency technical service providers, a paradigm that has largely failed, producers will receive a decision support system as part of their irrigation system purchase.

The future of Great Plains irrigation has often been viewed as tied to the steady decline of the High Plains aquifer. Recently, a second factor, climate change, has been added to the perspective, reducing expectations for precipitation and increasing the expectations for evaporative demand due to warming, particularly in the southern half of the Great Plains. Technical advances, however, have been largely ignored in predictions of the future, and they are a third factor in understanding what is to come. Improving irrigation technologies coupled with improving cultivars will improve crop water productivity and make irrigated agriculture more economically sustainable with decreasing water supply. However, technical improvements in irrigation management, methods, and equipment can only improve the effectiveness of using water for crop production; they cannot reduce pumping of the mostly non-renewable water resource in the southern part of the High Plains aquifer to sustainable levels. Thus, a fourth factor, water policy, is the key to future positive adaptation. In the end, either the aquifer will be pumped until the economically obtainable water for irrigation is exhausted, or the people of the Plains will institute additional policies and regulations that limit pumping to sustainable levels. Fortunately, the sustainability of irrigated agriculture with reduced water supplies has been greatly increased due to advances in irrigation application and management methods and crop varieties resulting from combined state, federal, and private research and development efforts. Coupled with the adaptability of the Great Plains population, this should allow a longer and smoother transition to less irrigated land in the Great Plains, To be sure, this will be only a partial victory, given the need for overall agricultural production increases to feed the future world.

\section{ACKNOWLEDGEMENTS}

This article is part of a center-pivot irrigation technology transfer effort supported by the USDA-ARS Ogallala Aquifer Program, a consortium between the USDA-ARS, Kansas State University, Texas A\&M AgriLife Research, Texas A\&M AgriLife Extension Service, Texas Tech University, and West Texas A\&M University. This material is based in part on work supported by the USDA National Institute of Food and Agriculture under Award No. 2016-67021-24420.

\section{REFERENCES}

Aandahl, A. R. (1982). Soils of the Great Plains: Land use, crops, and grasses. Lincoln, NE: University of Nebraska Press.
Retrieved from

http://www.jstor.org/discover/10.2307/2560702?uid=3739704\& uid=2129\&uid=2\&uid=70\&uid=4\&uid=3739256\&sid=2110339 4315993

Allen, R. G., Willardson, L. S., Burt, C., \& Clemmens, A. J. (2003). Water conservation questions and definitions from a hydrologic perspective. Proc. Intl. Irrigation Show (pp. 159-170). Retrieved from

https://www.irrigation.org/IA/FileUploads/IA/Resources/Tech nicalPapers/2003/WaterConservationDefinitionsFromAHydrol ogicPerspective.pdf

Allen, R. R., Musick, J. T., \& Wiese, A. F. (1976). Limited tillage of furrow irrigated winter wheat. Trans. ASAE, 19(2), 234-236. https://doi.org/10.13031/2013.36002

Almas, L. K., Colette, W. A., \& Park, S. C. (2006). Economic optimization of groundwater resources in the Texas Panhandle. Proc. Southern Agric. Econ. Assoc. (SAEA) Annual Meeting. Retrieved from http://ageconsearch.umn.edu/bitstream/35321/1/sp06al05.pdf Andales, A. A., Simmons, L. H., Bartolo, M. E., Straw, D., Chavez, J. L., Ley, T. W., \& Al Wahaibi, H. S. (2010). Alfalfa ET from a weighing lysimeter in the Arkansas Valley of Colorado. Proc. 5th National Decennial Irrigation Conf. St. Joseph, MI: ASABE. https://doi.org/10.13031/2013.35825

Andales, A., Straw, D., Ley, T., \& Berrada, A. (2009). Alfalfa reference ET from a weighing lysimeter and estimates from the ASCE standardized reference ET equation in the Arkansas Valley of Colorado. Proc. World Environmental and Water Resources Congress: Great Rivers (pp. 1-9). https://doi.org/10.1061/41036(342)414

Anderson, M., \& Kustas, W. (2008). Thermal remote sensing of drought and evapotranspiration. Eos, 89(26), 233-240. https://doi.org/10.1029/2008EO260001

Anderson, M., Gao, F., Knipper, K., Hain, C., Dulaney, W., Baldocchi, D., ... Kustas, W. (2018). Field-scale assessment of land and water use change over the California delta using remote sensing. Remote Sensing, 10(6), 889. https://doi.org/10.3390/rs10060889

ASCE. (2005). The ASCE standardized reference evapotranspiration equation. R. G. Allen, I. A. Walter, R. L. Elliott, T. A. Howell, D. Itenfisu, M. E. Jensen, \& R. I. Snyder, Eds. Reston, VA: ASCE. Retrieved from http://www.kimberly.uidaho.edu/water/asceewri/

Awal, R., \& Fares, A. (2018). Potential impact of climate change on irrigation water requirements for some major crops in the Northern High Plains of Texas. In O. Wendroth, R. J. Lascano, \& L. Ma (Eds.), Bridging among disciplines by synthesizing soil and plant processes (pp. 145-170). Madison, WI: ASA, CSSA, SSSA. https://doi.org/10.2134/advagricsystmodel8.2017.0014

Babbitt, C., Gibson, K., Sellers, S., Brozovic, N., Saracino, A., Hayden, A., ... Zellmer, S. (2018). The future of groundwater in California: Lessons in sustainable management from across the West. San Francisco, CA: Environmental Defense Fund.

Banda, M. M., Heeren, D. M., Martin, D. L., Munoz-Arriola, F., \& Hayde, L. G. (2019). Economic analysis of deficit irrigation in sugarcane farming: Nchalo Estate, Chikwawa District, Malawi. ASABE Paper No. 1900852. St. Joseph, MI: ASABE. https://doi.org/10.13031/aim.201900852

Barker, J. B., Heeren, D. M., Neale, C. M. U., \& Rudnick, D. R. (2018). Evaluation of variable-rate irrigation using a remotesensing-based model. Agric. Water Mgmt., 203, 63-74. https://doi.org/10.1016/j.agwat.2018.02.022

Bausch, W. C., \& Neale, C. M. U. (1987). Crop coefficients derived from reflected canopy radiation: A concept. Trans. ASAE, 30(3), 703-709. https://doi.org/10.13031/2013.30463 
Bleed, A., \& Babbitt, C. H. (2015). Nebraska's Natural Resources Districts: An assessment of a large-scale locally controlled water governance framework. Policy Report 1. Lincoln, NE: Daugherty Water for Food Global Institute.

Bordovsky, J. P. (2019). Low-energy precision application (LEPA) irrigation: A forty-year review. Trans. ASABE, 62(5), 13431353. https://doi.org/10.13031/trans.13117

Bordovsky, J. P., Lyle, W. M., Lascano, R. J., \& Upchurch, D. R. (1991). Cotton irrigation management with LEPA systems. Trans. ASAE, 35(3), 879-884. https://doi.org/10.13031/2013.28673

Briggs, L. J., \& Shantz, H. L. (1914). Relative water requirement of plants. J. Agric. Res., III(1), 1-64.

Camp, C. A., \& Lamm, F. R. (2003). Irrigation systems, subsurface drip. In S. W. Trimble (Ed.), Encyclopedia of water science. New York, NY: Taylor \& Francis Group.

Campos, I., Neale, C. M. U., Arkebauer, T. J., Suyker, A. E., \& Goncalves, I. Z. (2018). Water productivity and crop yield: A simplified remote sensing driven operational approach. Agric. Forest Meteorol., 249, 501-511. https://doi.org/10.1016/j.agrformet.2017.07.018

Campos, I., Neale, C. M. U., Suyker, A. E., Arkebauer, T. J., \& Goncalves, I. Z. (2017). Reflectance-based crop coefficients REDUX: For operational evapotranspiration estimates in the age of high-producing hybrid varieties. Agric. Water Mgmt., 187, 140-153. https://doi.org/10.1016/j.agwat.2017.03.022

CAST. (2019). Aquifer depletion and potential impacts on longterm irrigated agricultural productivity. Issue Paper 63. Ames, IA: Council for Agricultural Science and Technology.

CFWE. (2014). Citizen's guide to Colorado's transbasin diversions. Denver: Colorado Foundation for Water Education (currently Water Education Colorado). Retrieved from https://www.watereducationcolorado.org/publications-andradio/citizen-guides/citizens-guide-to-colorados-transbasindiversions/

Chávez, J. L., Pierce, F. J., Elliott, T. V., Evans, R. G., Kim, Y., \& Iversen, W. M. (2010). A remote irrigation monitoring and control system (RIMCS) for continuous-move systems: Part B. Field testing and results. Prec. Agric., 11(1), 11-26. https://doi.org/10.1007/s11119-009-9110-8

Chu, S. T., Bagherzadeh, M. H., DeBoer, D. W., \& ToghianiPozveh, A. (1992). Evaluation of trail-tube irrigation technology. Appl. Eng. Agric., 8(1), 41-46. https://doi.org/10.13031/2013.26031

Colaizzi, P. D., \& O’Shaughnessy, S. A. (2018). Web/smart phone based control and feedback systems for irrigation systems. In F. R. Lamm (Ed.), Proc. 30th Annual Central Plains Irrigation Conf. (pp. 199-208). Colby, KS: Central Plains Irrigation Association. Retrieved from https://www.ksre.kstate.edu/irrigate/oow/p18/Colaizzi18.pdf

Colaizzi, P. D., Evett, S. R., \& Howell, T. A. (2006). Near-surface soil water and temperature for SDI, LEPA, and spray irrigation. Proc. Tech. Conf. 27th Annual Intl. Irrigation Show (pp. 553566). Falls Church, VA: Irrigation Association. Retrieved from https://www.irrigation.org/IA/FileUploads/IA/Resources/Tech nicalPapers/2006/Near-

SurfaceSoilWaterAndTemperatureForSdiLepaAndSprayIrrigat ion.pdf

Colaizzi, P. D., Gowda, P. H., Marek, T. H., \& Porter, D. O. (2009). Irrigation in the Texas High Plains: A brief history and potential reductions in demand. Irrig. Drain., 58(3), 257-274. https://doi.org/10.1002/ird.418

Colaizzi, P. D., O'Shaughnessy, S. A., \& Evett, S. R. (2018). Calibration and tests of commercial wireless infrared thermometers. Appl. Eng. Agric., 34(4), 647-658. https://doi.org/10.13031/aea.12577
Colaizzi, P. D., Schneider, A. D., Evett, S. R., \& Howell, T. A. (2004). Comparison Of SDI, LEPA, and spray irrigation performance for grain sorghum. Trans. ASAE, 47(5), 1477-1492. https://doi.org/10.13031/2013.17628

Comas, L. H., Trout, T. J., DeJonge, K. C., Zhang, H., \& Gleason, S. M. (2019). Water productivity under strategic growth stagebased deficit irrigation in maize. Agric. Water Mgmt., 212, 433440. https://doi.org/10.1016/j.agwat.2018.07.015

Combs, S. (2014). Texas Water Report. Publication 96-1746. Austin, TX: Texas Comptroller of Public Accounts, Data Services Division. Retrieved from www.TXWaterReport.org.

CWCB. (2010). State water supply initiative. Denver, CO: Colorado Water Conservation Board. Retrieved from http://cwcb.state.co.us/water-management/water-supplyplanning/pages/swsi2010.aspx

CWCB. (2015). Colorado water plan. Denver, CO: Colorado Water Conservation Board. Retrieved from https://www.colorado.gov/pacific/cowaterplan/plan

DeBoer, D. W., \& Chu, S. T. (2001). Sprinkler technologies, soil infiltration, and runoff. J. Irrig. Drain. Eng., 127(4), 234-239. https://doi.org/10.1061/(ASCE)0733-9437(2001)127:4(234

DeJonge, K. C., Taghvaeian, S., Trout, T. J., \& Comas, L. H. (2015). Comparison of canopy temperature-based water stress indices for maize. Agric. Forest Meteorol., 156, 51-62. https://doi.org/10.1016/j.agwat.2015.03.023

Dong, X., Vuran, M. C., \& Irmak, S. (2013). Autonomous precision agriculture through integration of wireless underground sensor networks with center-pivot irrigation systems. Ad Hoc Networks, 11(7), 1975-1987. https://doi.org/10.1016/j.adhoc.2012.06.012

Dukes, M. D., \& Perry, C. (2006). Uniformity testing of variablerate center-pivot irrigation control systems. Prec. Agric., 7(3), 205. https://doi.org/10.1007/s11119-006-9020-y

Eck, H. V. (1986). Effects of water deficits on yield, yield components, and water use efficiency of irrigated corn. Agron. $J ., 78(6), 1035-1040$. https://doi.org/10.2134/agronj1986.00021962007800060020x

Eck, H. V., Mathers, A. C., \& Musick, J. T. (1987). Plant water stress at various growth stages and growth and yield of soybeans. Field Crops Res., 17(1), 1-16. https://doi.org/10.1016/0378-4290(87)90077-3

ECONorthwest. (2008). Irrigation in Montana: A program overview and economic analysis. Eugene, OR: ECONorthwest. Retrieved from www.econw.com

Elliott, J., Deryng, D., Muller, C., Frieler, K., Konzmann, M., Gerten, D., ... Wisser, D. (2014). Constraints and potentials of future irrigation water availability on agricultural production under climate change. Proc. Natl. Academy Sci., 111(9), 32393244. https://doi.org/10.1073/pnas. 1222474110

Elsayed, M. L., Anapalli, S., Ahuja, L., Ma, L., Trout, T. J., \& Andales, A. A. (2018). Modeling current and future climate effects on winter wheat production in Colorado, USA. In O. Wendroth, R. J. Lascano, \& L. Ma (Eds.), Bridging among disciplines by synthesizing soil and plan processes (pp. 171199). Madison, WI: ASA, CSSA, SSSA. https://doi.org/10.2134/advagricsystmodel8.2017.0015

Erhart, A. (1969). A page out of irrigation history: Early Kansas irrigation. Irrig. Age, (February), 20-CNI to 20-CN4.

Evans, R. G., Stevens, W. B., \& Iversen, W. M. (2006). Development of site-specific irrigation research under linearmove systems. Proc. 26th Annual Intl. Irrig. Technical Conf. Falls Church, VA: Irrigation Association.

Evett, S. R., Howell, T. A., \& Schneider, D. (1995). Energy and water balances for surface and subsurface drip irrigated corn. Microirrigation for a changing world: Conserving resources/preserving the environment. In F. R. Lamm (Ed.), 
Proc. 5th Intl. Microirrigation Congress (pp. 135-140). St. Joseph, MI: ASAE.

Evett, S. R., Howell, T. A., Schneider, A. D., Copeland, K. S., Dusek, D. A., Brauer, D. K., ... Gowda, P. H. (2016). The Bushland weighing lysimeters: A quarter century of crop ET investigations to advance sustainable irrigation. Trans. ASABE, 59(1), 163-179. https://doi.org/10.13031/trans.59.11159

Evett, S. R., Howell, T. A., Schneider, A. D., Upchurch, D. R., \& Wanjura, D. F. (1996). Canopy temperature based automatic irrigation control. In C. R. Camp, E. J. Sadler, \& R. E. Yoder (Eds.), Proc. Intl. Conf. Evapotranspiration and Irrigation Scheduling (pp. 207-213). St. Joseph, MI: ASAE.

Evett, S. R., Howell, T. A., Schneider, A. D., Upchurch, D. R., \& Wanjura, D. F. (2000a). Automatic drip irrigation of corn and soybean. In R. G. Evans, B. L. Benham, \& P. Trooien T. (Eds.), Proc. 4th Decennial Natl. Irrig. Symp. (pp. 401-408). St. Joseph, MI: ASAE.

Evett, S. R., Howell, T. A., Schneider, A. D., Wanjura, D. F., \& Upchurch, D. R. (2002). Automatic drip irrigation control regulates water use efficiency. Intl. Water Irrig., 22(2), 32-37.

Evett, S. R., Howell, T. A., Todd, R. W., Schneider, A. D., \& Tolk, J. A. (2000b). Alfalfa reference ET measurement and prediction. In R. G. Evans, B. L. Benham, \& P. Trooien T. (Eds.), Proc. 4th Decennial Natl. Irrig. Symp. (pp. 266-272). St. Joseph, MI: ASAE.

Evett, S. R., Marek, G. W., Colaizzi, P. D., Brauer, D. K., \& O'Shaughnessy, S. A. (2019). Corn and sorghum ET, E, yield, and CWP as affected by irrigation application method: SDI versus mid-elevation spray irrigation. Trans. ASABE, 62(5), 1377-1393. https://doi.org/10.13031/trans.13314

Evett, S. R., Mazahrih, N. T., Jitan, M. A., Sawalha, M. H., Colaizzi, P. D., \& Ayars, J. E. (2009). A weighing lysimeter for crop water use determination in the Jordan Valley, Jordan. Trans. ASABE, 52(1), 155-169. https://doi.org/10.13031/2013.25956

Evett, S. R., O’Shaughnessy, S. A., \& Peters, R. T. (2014). Irrigation scheduling and supervisory control data acquisition system for moving and static irrigation systems. U.S. Patent No. $8,924,031$ B1.

Evett, S. R., O’Shaughnessy, S. A., Colaizzi, P. D., Schwartz, R. C., \& Howell, T. A. (2013). Irrigated agriculture with limited water supply: Tools for understanding and managing irrigation and crop water use efficiencies. Abstract No. 96-1. Proc. ASA, CSSA, SSSA Intl. Annual Meeting. Madison, WI: ASA, CSSA, SSSA.

Evett, S. R., Peters, R. T., \& Howell, T. A. (2006). Controlling water use efficiency with irrigation automation: Cases from drip and center-pivot irrigation of corn and soybean. Proc. 28th Annual Southern Conservation Systems Conf. (pp. 57-66).

Evett, S. R., Schomberg, H. S., Thompson, A., Schwartz, R. C., O'Shaughnessy, S. A., \& Andrade, M. A. (2018). Water in the cloud: A new system for field water monitoring with cloud data access. Proc. Irrigation Association Technical Program. Falls Church, VA: Irrigation Association. Retrieved from https://www.irrigation.org/IA/FileUploads/IA/Resources/Tech nicalPapers/2018/Water_In_The_Cloud_EVETT.pdf

Farnsworth, R. K., Thompson, E. S., \& Peck, E. L. (1982). Evaporation atlas for the contiguous 48 United States. Technical Report NWS 33. Washington, DC: NOAA.

Fischbach, P. E., \& Somerhalder, B. R. (1971). Efficiencies of an automated surface irrigation system with and without a runoff re-use system. Trans. ASAE, 14(4), 717-719. https://doi.org/10.13031/2013.38375

Foster, T., Gonclalves, I. Z., Campos, I., Neale, C. M., \& Brozovic, N. (2019). Assessing landscape-scale heterogeneity in irrigation water use with remote sensing and in situ monitoring. Environ.
Res. Letters, 14(2), 024004. https://doi.org/10.1088/17489326/aaf2be

Fraisse, C. W., Heermann, D. F., \& Duke, H. R.-3. (1992). Modified linear-move system for experimental water application. In Advances in planning, design, and management of irrigation systems as related to sustainable land use (Vol. 1, pp. 367-376). Leuven, Belgium: Center for Irrigation Engineering.

Ganzel, B. (2009). Irrigation rushes in. Wessels Living History Farm website. Lincoln, NE: Ganzel Group Communications. Retrieved from http://www.livinghistoryfarm.org/farminginthe40s/water_01.ht $\mathrm{ml}$

Gibson, J. P., Franz, T. E., Wang, T., Gates, J., Grassini, P., Yang, H., \& Eisenhauer, D. E. (2017). A case study of field-scale maize irrigation patterns in western Nebraska: Implications for water managers and recommendations for hyper-resolution land surface modeling. Hydrol. Earth Syst. Sci., 21, 1051-1062. https://doi.org/10.5194/hess-21-1051-2017

Gibson, K. E. B., Yang, H. S., Franz, T., Eisenhauer, D., Gates, J. B., Nasta, P., ... Grassini, P. (2018). Assessing explanatory factors for variation in on-farm irrigation in U.S. maize-soybean systems. Agric. Water Mgmt., 197, 34-40. https://doi.org/10.1016/j.agwat.2017.11.008

Grafton, R. Q., Williams, J., Perry, C. J., Molle, F., Ringler, C., Steduto, P., ... Garrick, D. (2018). The paradox of irrigation efficiency. Science, 361(6404), 748-750. https://doi.org/10.1126/science.aat9314

Grassini, P., Yang, H., Irmak, S., Thorburn, J., Burr, C., \& Cassman, K. G. (2011). High-yield irrigated maize in the western U.S. Corn Belt: II. Irrigation management and crop water productivity. Field Crops Res., 120(1), 133-141. https://doi.org/10.1016/j.fcr.2010.09.013

Graterol, Y. E., Eisenhauer, D. E., \& Elmore, R. W. (1993). Alternate-furrow irrigation for soybean production. Agric. Water Mgmt., 24(2), 133-145. https://doi.org/10.1016/03783774(93)90004-T

Green, D. E. (1973). Land of the underground rain: Irrigation on the Texas High Plains, 1910-1970. Austin, TX: University of Texas Press.

Gurdak, J. J., \& Qi, S. L. (2006). Vulnerability of recently recharged ground water in the High Plains aquifer to nitrate contamination. USGS Scientific Investigations Report 20065050. Washington, DC: U.S. Geological Survey. https://doi.org/10.3133/sir20065050

Haghverdi, A., Yonts, C. D., Reichert, D. L., \& Irmak, S. (2017). Impact of irrigation, surface residue cover, and plant population on sugarbeet growth and yield, irrigation water use efficiency, and soil water dynamics. Agric. Water Mgmt., 180,1-12, https://doi.org/10.1016/j.agwat.2016.10.018

Han, J. C. (2016). Development of CornSoyWater, a web-based irrigation app for corn and soybean. PhD diss. Lincoln, NE: University of Nebraska, Department of Agronomy and Horticulture.

Han, M., Zhang, H., DeJonge, K. C., Comas, L. H., \& Gleason, S. (2018). Comparison of three crop water stress index models with sap flow measurements in maize. Agric. Water Mgmt., 203, 366375. https://doi.org/10.1016/j.agwat.2018.02.030

Han, Y. J., Khalilian, A., Owino, T. W., Farahani, H. J., \& Moore, S. (2009). Development of Clemson variable-rate lateral irrigation system. Comput. Electron. Agric., 68(1), 108-113.

Harris, I., Jones, P. D., Osborn, T. J., \& Lister, D. H. (2014). Updated high-resolution grids of monthly climatic observations: The CRU TS3.10 dataset. Intl. J. Climatol., 34(3), 623-642. https://doi.org/10.1002/joc.3711 
Hauser, V. L. (1959). Estimates of precision of moisture measurements made with the $\mathrm{d} / \mathrm{M}$ gauge neutron moisture meter during 1959. Bushland, TX: USDA-ARS Southwestern Great Plains Field Station, Western Soil and Water Management Research Branch.

Hedley, C. B., \& Yule, I. J. (2009). A method for spatial prediction of daily soil water status for precise irrigation scheduling. Agric. Water Mgmt., 96(12), 1737-1745. https://doi.org/10.1016/j.agwat.2009.07.009

Heeren, D. M., Trooien, T. P., Werner, H. D., \& Klocke, N. L. (2011). Development of deficit irrigation strategies for corn using a yield ratio model. Appl. Eng. Agric., 27(4), 605-614. https://doi.org/10.13031/2013.38207

Heermann, D. F., \& Hein, P. R. (1968). Performance characteristics of self-propelled center-pivot sprinkler irrigation system. Trans. ASAE, 11(1), 11-15. https://doi.org/10.13031/2013.39320

Heermann, D. F., Haise, H. R., \& Mickelson, R. H. (1976). Scheduling center-pivot sprinkler irrigation systems for corn production in eastern Colorado. Trans. ASAE, 19(2), 284-287. https://doi.org/10.13031/2013.36013

Heermann, D., \& Lamm, F. R. (2003). History of the Central Plains Irrigation Association (CPIA). Proc. Central Plains Irrigation Conf. Colby, KS: Central Plains Irrigation Association.

Henggeler, J. C. (1995). A history of drip-irrigated cotton in Texas. In F. R. Lamm (Ed.), Proc. 5th Intl. Microirrigation Congress: Microirrigation for a Changing World: Conserving Resources/Preserving the Environment (pp. 669-674). St. Joseph, MI: ASAE.

Hopmans, J. W., \& Maurer, E. (2007). Impact of climate change on irrigation water availability, crop water requirements, and soil salinity in the San Joaquin Valley. Berkeley, CA: University of California Water Resources Center.

Howell, T. A. (1997). What's in a name. Wetting Front, 1(2), 1-3.

Howell, T. A. (2006a). Water losses associated with center-pivot nozzle packages. Proc. Central Plains Irrigation Conf. (pp. 1124). Colby, KS: Central Plains Irrigation Association. Retreived from https://www.ksre.kstate.edu/irrigate/oow/p06/Howell06.pdf

Howell, T. A. (2006b). Challenges in increasing water use efficiency in irrigated agriculture. Proc. Intl. Symp. on Water and Land Management for Sustainable Irrigated Agriculture. Adana, Turkey: Cucurova University.

Howell, T. A., Evett, S. R., Tolk, J. A., \& Schneider, A. D. (2004). Evapotranspiration of full-, deficit-irrigated, and dryland cotton on the northern Texas High Plains. J. Irrig. Drain. Eng., 130(4), 277-285. https://doi.org/10.1061/(ASCE)07339437(2004)130:4(277)

Howell, T. A., Schneider, A. D., \& Evett, S. R. (1997a). Subsurface and surface microirrigation of corn: Southern High Plains. Trans. ASAE, 40(3), 635-641. https://doi.org/10.13031/2013.21322

Howell, T. A., Steiner, J. L., Schneider, A. D., Evett, S. R., \& Tolk, J. A. (1997b). Seasonal and maximum daily evapotranspiration of irrigated winter wheat, sorghum, and corn: Southern High Plains. Trans. ASAE, 40(3), 623-634. https://doi.org/10.13031/2013.21321

Howell, T. A., Tolk, J. A., Schneider, A. D., \& Evett, S. R. (1998). Evapotranspiration, yield, and water use efficiency of corn hybrids differing in maturity. Agron. J., 90(1), 3-9. https://doi.org/10.2134/agronj1998.00021962009000010002x

HPWD. (2014). High Plains Water District 2013 subsurface drip irrigation locations. Lubbock, TX: High Plains Water District. Retrieved from www.hpwd.org/s/SDI_2013.pdf

Hutson, W. F. (1898). Irrigation systems in Texas. USGS Water Supply and Irrigation Paper No. 13. Washington, DC: U.S. Geological Survey.
IPCC. (2013). Climate change 2013: The physical science basis. In T. F. Stocker, G. K. Plattner, M. Tignor, S. K. Allen, J. Boschung, \& P. M. Midgley (Eds.), Working Group 1 Contribution to the Intergovernmental Panel on Climate Change 5th Assessment Report (Vol. 1535). Cambridge, UK: Cambridge University Press.

Irmak, S., Kabenge, I., Skaggs, K. E., \& Mutiibwa, D. (2012). Trend and magnitude of changes in climate variables and reference evapotranspiration over 116-year period in the Platte River basin, central Nebraska, USA. J. Hydrol., 420-421, 228244. https://doi.org/10.1016/j.jhydrol.2011.12.006

Irmak, S., Mohammed, A. T., \& Kranz, W. L. (2019). Grain yield, crop and basal evapotranspiration, production functions, and water productivity response of drought-tolerant and nondrought-tolerant maize hybrids under different irrigation levels, population densities, and environments: Part II. In south-central Nebraska. Appl. Eng. Agric., 35(1), 83-102. https://doi.org/10.13031/aea.12871

Irmak, S., Rees, J. M., Zoubek, G. L., van DeWalle, B. S., Rathje, W. R., DeBuhr, R., ... Christiansen, A. P. (2010). Nebraska agricultural water management demonstration network (NAWMDN): Integrating research and extension/outreach. Appl. Eng. Agric., 26(4), 599-613.

https://doi.org/10.13031/2013.32066

Jensen, M. E., \& Sletten, W. H. (1957). Good irrigation management brings increased sorghum yields. Soil Water, 6, 89.

Jensen, M. E., \& Sletten, W. H. (1958). Irrigation water management for sorghum. Proc. Winter Meeting of the ASAE. St. Joseph, MI: ASAE.

Kamble, B., Kilic, A., \& Hubbard, K. (2013). Estimating crop coefficients using remote sensing-based vegetation index. Remote Sensing, 5(4), 1588-1602. https://doi.org/10.3390/rs5041588

Kemper, W. D., Heinemann, W. H., Kincaid, D. C., \& Worstell, R. V. (1981). Cablegation: I. Cable-controlled plugs in perforated supply pipes for automatic furrow irrigation. Trans. ASAE, 24(6), 1526-1532. https://doi.org/10.13031/2013.34485

Kim, Y., Evans, R. G., \& Iversen, W. M. (2008). Remote sensing and control of an irrigation system using a distributed wireless sensor network. IEEE Trans. Instrum. Meas., 57(7), 1379-1387. https://doi.org/10.1109/TIM.2008.917198

Kincaid, D. C., Heermann, D. F., \& Kruse, D. E. (1969). Application rates and runoff in center-pivot sprinkler irrigation. Trans. ASAE, 12(6), 790-794. https://doi.org/10.13031/2013.38955

Kipka, H., Green, T. R., David, O., Garcia, L. A., Ascough II, J. C., \& Arabi, M. (2015). Development of the land-use and agricultural management practice web-service (LAMPS) for generating crop rotations in space and time. Soil Tillage Res., 155, 233-249. https://doi.org/10.1016/j.still.2015.08.005

Kisekka, I., Oker, T., Nguyen, G., Aguilar, J., \& Rogers, D. (2016). Mobile drip irrigation evaluation in corn. Research reports, 2(7). Manhattan, KS: Kansas Agricultural Experiment Station. https://doi.org/10.4148/2378-5977.1253

Klocke, N. L., Currie, R. S., \& Aiken, R. M. (2009). Soil water evaporation and crop residues. Trans. ASABE, 52(1), 103-110. https://doi.org/10.13031/2013.25951

Kohl, R. A., \& DeBoer, D. W. (1984). Drop size distributions for a low-pressure spray type agricultural sprinkler. Trans. ASAE, 27(6), 1836-1840. https://doi.org/10.13031/2013.33054

Kranz, W. L., Evans, R. G., Lamm, F. R., O’Shaughnessy, S. A., \& Peters, R. T. (2012). A review of mechanical-move sprinkler irrigation control and automation technologies. Appl. Eng. Agric., 28(3), 389-397. https://doi.org/10.13031/2013.41494 
Kukal, M., \& Irmak, S. (2018). Climate-driven crop yield and yield variability and climate change impacts on the U.S. Great Plains agricultural production. Nature Sci. Reports, 8(1), 3450. https://doi.org/10.1038/s41598-018-21848-2

Kukal, M., Irmak, S., \& Kilic, A. (2017). Long-term spatial and temporal maize and soybean evapotranspiration trends derived from ground-based and satellite-based datasets over the Great Plains. J. Irrig. Drain. Eng., 143(9), 04017031. https://doi.org/10.1061/(ASCE)IR.1943-4774.0001212

Kullberg, E. G., DeJonge, K. C., \& Chavez, J. L. (2017). Evaluation of thermal remote sensing indices to estimate crop evapotranspiration coefficients. Agric. Water Mgmt., 179, 64-73. https://doi.org/10.1016/j.agwat.2016.07.007

Lamm, F. R. (2016). Cotton, tomato, corn, and onion production with subsurface drip irrigation: A review. Trans. ASABE, 59(1), 263-278. https://doi.org/10.13031/trans.59.11231

Lamm, F. R., \& Rogers, D. H. (1985). Soil water recharge function as a tool for preseason irrigation. Trans. ASAE, 28(5), 15211525. https://doi.org/10.13031/2013.32470

Lamm, F. R., \& Trooien, T. P. (2003). Subsurface drip irrigation for corn production: A review of 10 years of research in Kansas. Irrig. Sci., 22(3), 195-200. 1https://doi.org/0.1007/s00271-0030085-3

Lamm, F. R., Aiken, R. M., \& Abou Kheira, A. A. (2009). Corn yield and water use characteristics as affected by tillage, plant density, and irrigation. Trans. ASABE, 52(1), 133-143. https://doi.org/10.13031/2013.25954

Lamm, F. R., Bordovsky, J. P., \& Howell Sr, T. A. (2019a). A review of in-canopy and near-canopy sprinkler irrigation concepts. Trans. ASABE, 62(5), 1355-1364. https://doi.org/10.13031/trans.13229

Lamm, F. R., Bordovsky, J. P., Schwankl, L. J., Grabow, G. L., Enciso-Medina, J., Peters, T. R., ... Porter, D. O. (2012). Surface drip irrigation: Status of the technology in 2010. Trans. ASABE, 55(2), 483-491. https://doi.org/10.13031/2013.41387

Lamm, F. R., Colaizzi, P. D., Bordovsky, J. P., Trooien, T. P., Enciso-Medina, J., Porter, D. O., ... O'Brien, D. M. (2010). Can subsurface drip irrigation (SDI) be a competitive irrigation system in the Great Plains region for commodity crops? Proc. 5th National Decennial Irrigation Conf. ASABE Paper No. IRR109686. St. Joseph, MI: ASABE.

Lamm, F. R., Howell, T. A., \& Bordovsky, J. P. (2006). Concepts of in-canopy and near-canopy sprinkler irrigation. Proc. ASCEEWRI Water Congress. Reston, VA: ASCE. https://doi.org/10.1061/40856(200)284

Lamm, F. R., Howell, T. A., \& Bordovsky, J. P. (2007). Ensuring equal-opportunity sprinkler irrigation. ASABE Paper No. IA071013. St. Joseph, MI: ASABE.

Lamm, F. R., Manges, H. L., Stone, L. R., Khan, A. H., \& Rogers, D. H. (1995). Water requirement of subsurface drip-irrigated corn in northwest Kansas. Trans. ASAE, 38(2), 441-448. https://doi.org/10.13031/2013.27851

Lamm, F. R., Porter, D. O., Bordovsky, J. P., Evett, S. R., O'Shaughnessy, S. A., Stone, K. C., ... Colaizzi, P. D. (2019b). Targeted, precision irrigation for moving platforms: Selected papers from a center-pivot technology transfer effort. Trans. ASABE, 62(5), 1409-1415. https://doi.org/10.13031/trans.13371

Ledbetter, K. (2019). Cotton acreage continues climb in northern Texas Panhandle. AgriLife Today (14 March 2019). Retrieved from https://today.agrilife.org/2019/03/14/cotton-acreagecontinues-climb-in-northern-texas-panhandle/

Lo, T., Heeren, D. M., Martin, D. L., Mateos, L., Luck, J. D., \& Eisenhauer, D. E. (2016). Pumpage reduction by using variablerate irrigation to mine undepleted soil water. Trans. ASABE, 59(5), 1285-1298. https://doi.org/10.13031/trans.59.11773
Lyle, W. M., \& Bordovsky, J. P. (1983). LEPA irrigation system evaluation. Trans. ASAE, 26(3), 776-781. https://doi.org/10.13031/2013.34022

Mace, R. E., Petrossian, R., Bradley, R., \& Mullican III, W. F. (2006). A streetcar named desired conditions: The new groundwater availability for Texas. Proc. 7th Annual State Bar of Texas the Changing Face of Water Rights in Texas. Retrieved from

http://ccgcd.org/Reports/A\%20Street $\% 20$ Car\%20Named $\% 20$ Desired\%20Future\%20Conditions.pdf

Marek, T. H., Scherer, T., Porter, D., Rogers, D., Henggeler, J., \& Howell, T. A. (2010). What will it take to get irrigators to use advisory programs? Lessons learned from the past ten years and beyond. ASABE Paper No. IRR10-9683. St. Joseph, MI: ASABE.

Marek, T. H., Schneider, A. D., Howell, T. A., \& Ebeling, L. L. (1988). Design and construction of large weighing monolithic lysimeters. Trans. ASAE, 31(2), 477-484. https://doi.org/10.13031/2013.30734

Marek, T., Howell, T., New, L., Bean, B., Dusek, D., \& Michels Jr., G. J. (1996). Texas North Plains PET network. In C. R. Camp, E. J. Sadler, \& R. E. Yoder (Eds.), Proc. Intl. Conf. Evapotranspiration and Irrigation Scheduling (pp. 710-715). St. Joseph, MI: ASAE.

Marek, T., Piccinni, G., Schneider, A., Howell, T., Jett, M., \& Dusek, D. (2006). Weighing lysimeters for the determination of crop water requirements and crop coefficients. Appl. Eng. Agric., 22(6), 851-856. https://doi.org/10.13031/2013.22256

Martin, D. L., Kranz, W. L., Smith, T., Irmak, S., Burr, C., \& Yoder, R. E. (2017). Center-pivot irrigation handbook. Publication EC3017. Lincoln, NE: University of Nebraska Extension.

Martin, D. L., Stegman, E. C., \& Fereres, E. (1990). Irrigation scheduling principles. In Management of farm irrigation systems (pp. 155-177). St. Joseph, MI: ASAE.

Martin, D. L., Supalla, R. J., Thompson, C. L., McMullen, B. P., Hergert, G. W., \& Bergener, P. A. (2010). Advances in deficit irrigation management. ASABE Paper No. IRR10-9277. St. Joseph, MI: ASABE.

Martin, D. L., Watts, D. G., \& Gilley, J. R. (1984). Model and production function for irrigation management. J. Irrig. Drain. Eng., 110(2), 149-164. https://doi.org/10.1061/(ASCE)07339437(1984)110:2(149)

McCornick, P. G., Duke, H. R., \& Podmore, T. H. (1988). Field evaluation procedure for surge irrigation. Trans. ASAE, 31(1), 168-177. https://doi.org/10.13031/2013.30683

McDonald, R. I., \& Girvetz, E. H. (2013). Two challenges for U.S. irrigation due to climate change: Increasing irrigated area in wet states and increasing irrigation rates in dry states. PLoS One, 8(6), e65589. https://doi.org/10.1371/journal.pone.0065589

McGuire, V. L. (2014). Water-level changes and change in water in storage in the High Plains aquifer, predevelopment to 2013 and 2011-13. USGS Scientific Investigations Report 2014-5218. Reston, VA: U.S. Geological Survey. https://doi.org/10.3133/sir20145218

McGuire, V. L., Lund, K. D., \& Densmore, B. K. (2012). Saturated thickness and water in storage in the High Plains aquifer, 2009, and water-level changes and changes in water in storage in the High Plains aquifer, 1980 to 1995,1995 to 2000, 2000 to 2005, and 2005 to 2009 . USGS Scientific Investigations Report 20125177. Reston, VA: U.S. Geological Survey. https://doi.org/10.3133/sir20125177

McMaster, G. S., Ascough II, J. C., Edmunds, D. A., Nielsen, D. C., \& Prasad, P. V. V. (2013). Simulating crop phenological responses to water stress using the PhenologyMMS software 
program. Appl. Eng. Agric., 29(2), 233-249.

https://doi.org/10.13031/2013.42654

McMaster, G. S., Ascough II, J. C., Edmunds, D. A., Wagner, L. E., Fox, F. A., DeJonge, K. C., \& Hansen, N. C. (2014). Simulating unstressed crop development and growth using the unified plant growth model (UPGM). Environ. Model. Assess., 19(5), 407424. https://doi.org/10.1007/s10666-014-9402-x

Miksinski Jr., T. A. (1998). The Great Plains and prairies. In S. S. Birdsall, \& J. Florin (Eds.), An outline of American geography: Regional landscapes of the United States. Washington, DC: U.S. Information Agency.

Munoz-Arriola, F., Martin, D. L., \& Eisenhauer, D. E. (2014). Nebraska's water resources in changing climate. In Understanding and assessing climate change: Implications for Nebraska. Lincoln, NE: University of Nebraska.

Musick, J. T., \& Dusek, D. A. (1980). Irrigated corn yield response to water. Trans. ASAE, 23(1), 92-98.

https://doi.org/10.13031/2013.34531

Musick, J. T., \& Dusek, D. A. (1982). Skip-row planting and irrigation of graded furrows. Trans. ASAE, 25(1), 82-87. https://doi.org/10.13031/2013.33481

Musick, J. T., \& Lamm, F. R. (1990). Preplant irrigation in the Central and Southern High Plains: A review. Trans. ASAE, 33(6), 1835-1842. https://doi.org/10.13031/2013.31547

Musick, J. T., \& Pringle, F. B. (1986). Tractor wheel compaction of wide-spaced irrigated furrows for reducing water application. Appl. Eng. Agric., 2(2), 123-128. https://doi.org/10.13031/2013.26725

Musick, J. T., \& Walker, J. D. (1987). Irrigation practices for reduced water application: Texas High Plains. Appl. Eng. Agric., 3(2), 190-195. https://doi.org/10.13031/2013.26671

Musick, J. T., Jones, O. R., Stewart, B. A., \& Dusek, D. A. (1994). Water-yield relationships for irrigated and dryland wheat in the U.S. Southern Plains. Agron. J., 86(6), 980-986. https://doi.org/10.2134/agronj1994.00021962008600060010x

Musick, J. T., Pringle, F. B., \& Johnson, P. N. (1985). Furrow compaction for controlling excessive irrigation water intake. Trans. ASAE, 28(2), 502-506. https://doi.org/10.13031/2013.32286

Musick, J. T., Pringle, F. B., \& Walker, J. D. (1988). Sprinkler and furrow irrigation trends: Texas High Plains. Appl. Eng. Agric., 4(1), 46-52. https://doi.org/10.13031/2013.26578

Musick, J. T., Pringle, F. B., Harman, W., \& Stewart, B. (1990). Long-term irrigation trend: Texas High Plains. Appl. Eng. Agric., 6(6), 717-724. https://doi.org/10.13031/2013.26454

NDNR. (2018). Registered groundwater wells data retrieval. Nebraska Department of Natural Resources. Retrieved from http://nednr.nebraska.gov/Dynamic/Wells/Wells/WellsSearch?U seIds $=7 \&$ StatusIds $=1$

NDR. (2018). Irrigated acres in Nebraska 1964-2016. Lincoln, NE: Nebraska Department of Revenue, Property Assessment Division. Retrieved from http://www.neo.ne.gov/statshtml/73b.html

Neale, C. M. U., Bausch, W. C., \& Heermann, D. (1990). Development of reflectance-based crop coefficients for corn. Trans. ASAE, 32(6), 1891-1900. https://doi.org/10.13031/2013.31240

Nebraska Water Center. (2018). Reflections on Nebraska's irrigation legacy. Water Current, 50(2).

New, L. L. (1986). Center-pivot irrigation systems. Leaflet 2219. College Station, TX: Texas Agricultural Extension Service. Retrieved from http://hdl.handle.net/1969.1/174873.

Nielsen, D. C. (1998). Snow catch and soil water recharge in standing sunflower residue. J. Prod. Agric., 11(4), 476-480. https://doi.org/10.2134/jpa1998.0476
Nostrand, R. L. (1996). The Hispano homeland. Norman, OK: University of Oklahoma Press.

Odhiambo, L. O., \& Irmak, S. (2012). Evaluation of the impact of surface residue cover on single and dual crop coefficient for estimating soybean actual evapotranspiration. Agric. Water Mgmt., 104, 221-234. https://doi.org/10.1016/j.agwat.2011.12.021

OgallalaWater. (2019). Irrigation scheduling tools. Retrieved from https://ogallalawater.org/irrigation-scheduling-tools/

O’Shaughnessy, S. A., \& Evett, S. R. (2010a). Canopy temperature based system effectively schedules and controls center-pivot irrigation of cotton. Agric. Water Mgmt., 97(9), 1310-1316. https://doi.org/10.1016/j.agwat.2010.03.012

O'Shaughnessy, S. A., \& Evett, S. R. (2010b). Developing wireless sensor networks for monitoring crop canopy temperature using a moving sprinkler system as a platform. Appl. Eng. Agric., 26(2), 331-341. https://doi.org/10.13031/2013.29534

O’Shaughnessy, S. A., Evett, S. R., \& Colaizzi, P. D. (2015). Dynamic prescription maps for site-specific variable-rate irrigation of cotton. Agric. Water Mgmt., 159, 123-138. https://doi.org/10.1016/j.agwat.2015.06.001

O’Shaughnessy, S. A., Evett, S. R., Andrade, A., Workneh, F., Price, J. A., \& Rush, C. M. (2016). Site-specific variable-rate irrigation as a means to enhance water use efficiency. Trans. ASABE, 59(1), 239-249. https://doi.org/10.13031/trans.59.11165

O’Shaughnessy, S. A., Evett, S. R., Colaizzi, P. D., \& Howell, T. A. (2012). Automating prescription map building for VRI systems using plant feedback. Proc. Irrigation Association Show and Education Conf. Irrigation Association.

O’Shaughnessy, S. A., Evett, S. R., Colaizzi, P. D., \& Howell, T. A. (2013b). Wireless sensor network effectively controls centerpivot irrigation of sorghum. Appl. Eng. Agric., 29(6), 853-864. https://doi.org/10.13031/aea.29.9921

O’Shaughnessy, S. A., Evett, S. R., Colaizzi, P. D., Andrade, M. A., Marek, T. H., Heeren, D. M., ... LaRue, J. L. (2019). Identifying advantages and disadvantages of variable-rate irrigation: An updated review. Appl. Eng. Agric., 35(6), 837-852. https://doi.org/10.13031/aea.13128

O’Shaughnessy, S. A., Urrego, Y. F., Evett, S. R., Colaizzi, P. D., \& Howell, T. A. (2013a). Assessing application uniformity of a variable-rate irrigation system in a windy location. Appl. Eng. Agric., 29(4), 497-510. https://doi.org/http://dx.doi.org/10.13031/aea.29.9931

Oswald, J. K., \& Werner, H. D. (2009). On-line irrigation scheduling within the Belle Fourche Irrigation District. Proc. World Environmental and Water Resources Congress (pp. 40584067). Reston, VA: ASCE. https://doi.org/10.1061/41036(342)410

Ou, G., Munoz-Arriola, F., Uden, D. R., Martin, D., Allen, C. R., \& Shank, N. (2018). Climate change implications for irrigation and groundwater in the Republican River basin, USA. Climatic Change, 151(2), 303-316. https://doi.org/10.1007/s10584-0182278-Z

Payero, J. O., Melvin, S., \& Irmak, S. (2005). Response of soybean to deficit irrigation in the semi-arid environment of west-central Nebraska. Trans. ASAE, 48(6), 2189-2203. https://doi.org/10.13031/2013.20105

Payero, J. O., Tarkalson, D. D., Irmak, S., Davison, D., \& Petersen, J. L. (2009). Effect of timing of a deficit-irrigation allocation on corn evapotranspiration, yield, water use efficiency, and dry mass. Agric. Forest Meteorol., 96(10), 1387-1397. https://doi.org/10.1016/j.agwat.2009.03.022

Peters, R. T., \& Evett, S. R. (2008). Automation of a center pivot using the temperature-time-threshold method of irrigation scheduling. J. Irrig. Drain. Eng., 134(3), 286-291. https://doi.org/10.1061/(ASCE)0733-9437(2008)134:3(286) 
Phene, C. J., Howell, T. A., \& Sikorski, M. D. (1985). A traveling trickle irrigation system. Adv. Irrig., 3, 1-49. https://doi.org/10.1016/B978-0-12-024303-7.50006-6

Rawlins, S. L., Hoffman, G. J., \& Merrill, S. C. (1974). Traveling trickle system. Proc. 2nd Drip Irrigation Congress (pp. 184187). Riverside, CA: University of California.

Rogers, D. H., \& Lamm, F. R. (2012). Kansas irrigation trends. Proc. 24th Annual Central Plains Irrigation Conf. (pp. 1-15). Colby, KS: Central Plains Irrigation Association. Retrieved from http://www.ksre.ksu.edu/irrigate/OOW/P12/Rogers12Trends.pdf

Rogers, D., \& Wilson, B. B. (2000). Kansas irrigation systems and cropping trends. In An atlas of the Kansas High Plains Aquifer. Lawrence, KS: Kansas Geological Survey. Retrieved from http://www.kgs.ku.edu/HighPlains/atlas/index.html\#Atlas_Direc tory

Rolland, L. (1982). Mechanized sprinkler irrigation. FAO Irrigation and Drainage Paper No. 35. Rome, Italy: United Nations FAO.

Rudnick, D. R., Irmak, S., West, C., Chávez, J. L., Kisekka, I., Marek, T. H., ... Schlegel, A. (2019). Deficit irrigation management of maize in the High Plains aquifer region: A review. JAWRA, 55(1), 38-55. https://doi.org/10.1111/17521688.12723

Salam, A., Vuran, M. C., \& Irmak, S. (2019). Di-Sense: In situ realtime permittivity estimation and soil moisture sensing using wireless underground communications. Comput. Networks, 151, 31-41. https://doi.org/10.1016/j.comnet.2019.01.001

Scanlon, B. R., Faunt, C. C., Longuevergne, L., Reedy, R. C., Alley, W. M., McGuire, V. L., \& McMahon, P. B. (2012). Groundwater depletion and sustainability of irrigation in the U.S. High Plains and Central Valley. Proc. Natl. Acad. Sci., 109(24), 9320-9325. https://doi.org/10.1073/pnas.1200311109

Scherer, T. F., \& Morlock, D. J. (2008). A site-specific web-based irrigation scheduling program. ASABE Paper No. 083589. St. Joseph, MI: ASABE.

Schneider, A. D. (1976). Irrigation tailwater loss and utilization equations. J. Irrig. Drain. Div., 102(4), 461-464.

Schneider, A. D. (2000). Efficiency and uniformity of the LEPA and spray sprinkler methods: A review. Trans. ASAE, 43(4), 937-944. https://doi.org/10.13031/2013.2990

Schneider, A. D., \& Howell, T. A. (1993). Sprinkler application methods and sprinkler system capacity. ASAE Paper No. 932053. St. Joseph, MI: ASAE.

Schneider, A. D., \& Howell, T. A. (1994). Methods, amounts, and timing of sprinkler irrigation for winter wheat. ASAE Paper No. 942590. St. Joseph, MI: ASAE.

Schneider, A. D., \& Howell, T. A. (1995a). LEPA and spray irrigation in the Southern High Plains. In W. H. Espey Jr. \& P. G. Combs (Eds.), Water resources engineering (Vol. 2, pp. 1718-1722). Reston, VA: ASCE.

Schneider, A. D., \& Howell, T. A. (1995b). Grain sorghum response to sprinkler application methods and system capacity. Trans. ASABE, 38(6), 1693-1697. https://doi.org/10.13031/2013.27996

Schneider, A. D., \& Howell, T. A. (1998). LEPA and spray irrigation of corn: Southern High Plains. Trans. ASAE, 41(5), 1391-1396. https://doi.org/10.13031/2013.17313

Schneider, A. D., \& Howell, T. A. (1999). LEPA and spray irrigation for grain crops. J. Irrig. Drain. Eng., 125(4), 167-172. Retrieved from https://doi.org/10.1061/(ASCE)07339437(1999)125:4(167)

Schneider, A. D., Ayars, J. E., \& Phene, C. J. (1993). Combining monolithic and repacked soil tanks for high water table lysimeters. ASAE Paper No. 932552. St. Joseph, MI: ASAE.

Schneider, A. D., Buchleiter, G. W., \& Kincaid, D. C. (2000). LEPA irrigation developments. In R. G. Evans, B. L. Benham,
\& P. Trooien. T. (Eds.), Proc. 4th Decennial National Irrigation Symp. (pp. 89-96). St. Joseph, MI: ASAE.

Schneider, A. D., Howell, T. A., \& Evett, S. R. (2001). Comparison of SDI, LEPA, and spray irrigation efficiency. ASAE Paper No. 012019. St. Joseph, MI: ASAE. https://doi.org/10.13031/2013.7374

Schneider, A. D., Howell, T. A., Moustafa, A. T. A., Evett, S. R., \& Abou-Zeid, W. (1998). Asimplified weighing lysimeter for monolithic or reconstructed soils. Appl. Eng. Agric., 14(3), 267273. https://doi.org/10.13031/2013.19388

Schoengold, K., \& Brozovic, N. (2018). The future of groundwater management in the High Plains: Evolving institutions, aquifers, and regulations. Western Econ. Forum, 16(1), 47-53.

Schwartz, R. C., Evett, S. R., Anderson, S. K., \& Anderson, D. J. (2016). Evaluation of a direct-coupled time-domain reflectometry for determination of soil water content and bulk electrical conductivity. Vadose Zone J., 15(1), vzj2015.08.0115. https://doi.org/10.2136/vzj2015.08.0115

Steward, D. R., \& Allen, A. J. (2016). Peak groundwater depletion in the High Plains aquifer, projections from 1930 to 2110 . Agric. Water Mgmt., 170, 36-48. https://doi.org/10.1016/j.agwat.2015.10.003

Steward, D. R., Bruss, P. J., Yang, X., Staggenborg, S. A., Welch, S. M., \& Apley, M. D. (2013). Tapping unsustainable groundwater stores for agricultural production in the High Plains aquifer of Kansas, projections to 2110. Proc. Natl. Acad. Sci., 110, E3477-E3486. Retrieved from www.pnas.org/cgi/doi/10.1073/pnas.1220351110

Stewart, B. A., Musick, J. T., \& Dusek, D. A. (1983). Yield and water use efficiency of grain sorghum in a limited irrigationdryland farming system. Agron. J., 75(4), 629-634. https://doi.org/10.2134/agronj1983.00021962007500040013x

Stone, L. R., Lamm, F. R., Schlegel, A. J., \& Klocke, N. L. (2008). Storage efficiency of off-season irrigation. Agron. J., 100(4), 1185-1192. https://doi.org/10.2134/agronj2007.0242

Suarez, F. G., Fulginiti, L. E., \& Perrin, R. K. (2018). What is the use value of irrigation water from the High Plains aquifer? American J. Agric. Econ., 101(2), 455-466. https://doi.org/10.1093/ajae/aay062

Taghvaeian, S., Chávez, J. L., Bausch, W. C., DeJonge, K. C., \& Trout, T. J. (2014a). Minimizing instrumentation requirement for estimating crop water stress index and transpiration of maize. Irrig. Sci., 32(1), 53-65. https://doi.org/10.1007/s00271-0130415-z

Taghvaeian, S., Comas, L., DeJonge, K. C., \& Trout, T. J. (2014b). Conventional and simplified canopy temperature indices predict water stress in sunflower. Agric. Water Mgmt., 144, 69-80. https://doi.org/10.1016/j.agwat.2014.06.003

Tebaldi, C., Hayhoe, K., Arblaster, J. M., \& Meehl, G. A. (2006). Going to the extremes: An intercomparison of model-simulated historical and future changes in extreme events. Climatic Change, 79(3-4), 185-211. https://doi.org/10.1007/s10584-0069051-4

Thoburn, J. B. (1926). A progress report on Oklahoma archeology. Proc. Oklahoma Acad. Sci., 6(2), 369-371.

Thoburn, J. B. (1931). Ancient irrigation ditches on the Plains. Chronicles Oklahoma, 9(1), 56-62.

Trimble, D. E. (1980). The geologic story of the Great Plains. USGS Bulletin 1493. Reston, VA: U.S. Geological Survey.

Trout, T. J., \& DeJonge, K. C. (2017). Water productivity of maize in the U.S. High Plains. Irrig. Sci., 35(3), 251-266. https://doi.org/10.1007/s00271-017-0540-1

Trout, T. J., \& Kincaid, D. C. (1994). Cablegation evaluation methodology. Appl. Eng. Agric., 9(6), 523-528. https://doi.org/10.13031/2013.26017 
Trout, T. J., Kincaid, D. C., \& Kemper, W. D. (1990). Cablegation: A review of the past decade and prospects for the next. Proc. 3rd Natl. Irrigation Symp. Visions of the Future (pp. 21-27). St. Joseph, MI: ASAE.

TWDB. (2001). Surveys of irrigation in Texas, 1958, 1964, 1969, 1974, 1979, 1984, 1989, 1994, and 2000. Austin, TX: Texas Water Development Board, Report 347. TWDB. Retrieved from https://www.twdb.texas.gov/publications/reports/numbered_rep orts/

TWDB. (2011). Irrigation metering and water use estimates: A comparative analysis, 1999-2007. Report 378. Austin, TX: Texas Water Development Board. Retrieved from https://www.twdb.texas.gov/publications/reports/numbered_rep orts/

TWDB. (2012). Water for Texas: 2012 State water plan. Austin, TX: Texas Water Development Board. Retrieved from https://www.twdb.texas.gov/waterplanning/swp/2012/index.asp

Unger, P. W. (1976). Surface residue, water application, and soil texture effects on water accumulation. SSSA J., 40(2), 298-300. https://doi.org/10.2136/sssaj1976.03615995004000020027x

Unger, P. W. (1983). Irrigation effect on sunflower growth, development, and water use. Field Crops Res., 7, 181-194. https://doi.org/10.1016/0378-4290(83)90021-7

Unger, P. W. (1984). Tillage and residue effects on wheat, sorghum, and sunflower grown in rotation. SSSA J., 48(4), 885-891. https://doi.org/10.2136/sssaj1984.03615995004800040037x

Unger, P. W., \& Baumhardt, R. L. (1999). Factors related to dryland grain sorghum yield increases: 1939 through 1997. Agron. J., 91(5), 870-875. 10.2134/agronj1999.915870x

Unger, P. W., \& Wiese, A. F. (1979). Managing irrigated winter wheat residues for water storage and subsequent dryland grain sorghum production. SSSA J., 43(3), 582-588. https://doi.org/10.2136/sssaj1979.03615995004300030030x

UNL. (1977). Center-pivot irrigation systems in Nebraska. Lincoln, NE: University of Nebraska Remote Sensing Center.

USDA-ARS. (2019). MonDak irrigation overview. Sidney, MT: USDA-ARS Northern Plains Agricultural Research Laboratory. Retrieved from https://www.ars.usda.gov/plains-area/sidney$\mathrm{mt} /$ northern-plains-agricultural-research-laboratory/nparldocs/irrigation-info/mondak-irrigation-overview/

USDA-ERS. (2019). Federal government direct farm program payments, 2010-2019F nominal (current dollars). Washington, DC: USDA Economic Research Service. Retrieved from https://data.ers.usda.gov/reports.aspx?ID=17833

USDA-NASS. (1998). Farm and ranch irrigation survey. In 1997 Census of agriculture, Vol. 3, Special studies, Part 1 (AC97-SP1). Washington, DC: USDA-NASS.

USDA-NASS. (2002). Farm and ranch irrigation report. In 2001 Census of agriculture. Washington, DC: USDA National Agricultural Statistics Service. Retrieved from http://www.agcensus.usda.gov/Publications/2002/FRIS/
USDA-NASS. (2008). Farm and ranch irrigation survey. In 2007 Census of agriculture. Washington, DC: USDA National Agricultural Statistics Service. Retrieved from http://www.agcensus.usda.gov/Publications/2007/Online_Highli ghts/Farm_and_Ranch_Irrigation_Survey/index.php

USDA-NASS. (2013). Farm and ranch irrigation survey. In 2012 Census of agriculture, Vol. 3, Special studies, Part 1 (AC-12SS-1). Washington, DC: USDA National Agricultural Statistics Service.

USDA-NASS. (2019a). Irrigation and water management survey In 2018 Census of agriculture, Vol. 3, Special studies, Part 1 (AC17-SS-1). Washington, DC: USDA National Agricultural Statistics Service.

USDA-NASS. (2019b). United States summary and stated data. In 2018 Census of agriculture, Vol. 1, Geographic area series, Part 51 (AC-17-A-51). Washington, DC: USDA National Agricultural Statistics Service.

van Donk, S. J., Martin, D. L., Irmak, S., Melvin, S. R., Petersen, J. L., \& Davison, D. R. (2010). Crop residue cover effects on evaporation, soil water content, and yield of deficit-irrigated corn in west-central Nebraska. Trans. ASABE, 53(6), 1787-1797. https://doi.org/10.13031/2013.35805

Van Hook, J. (1933). Development of irrigation in the Arkansas Valley. Colorado Magazine, 10(1).

Vellidis, G., Tucker, M., Perry, C., Kvien, C., \& Bednarz. C. (2008). A real-time wireless smart sensor array for scheduling irrigation. Comput. Electron. Agric., 61, 44-50. https://doi.org/10.1016/j.compag.2007.05.009

Wanjura, D. F., Upchurch, D. R., \& Mahan, J. R. (1992). Automated irrigation based on threshold canopy temperature. Trans. ASAE, 35(1), 153-159. https://doi.org/10.13031/2013.28582

Werner, H. D. (1993). Checkbook irrigation scheduling. Publication EC897. Brookings, SD: South Dakota State University Cooperative Extension Service.

Woldt, W. E., Neale, C. M., Heeren, D. M., Frew, E., \& Meyer, G. E. (2018). Improving agricultural water efficiency with unmanned aircraft. XPONENTIAL Trade Show and Conf. Arlington, VA: Association for Unmanned Vehicle Systems International (AUVSI).

Xue, Q., Marek, T. H., Xu, W., \& Bell, J. (2017). Irrigated corn production and management in the Texas High Plains. $J$. Contemp. Water Res. Educ., 162(1), 31-41. https://doi.org/10.1111/j.1936-704X.2017.03258.x

Younts, C. D., Eisenhauer, D. E., \& Fekersillassie, D. (1996). Impact of surge irrigation on furrow water advance. Trans. ASAE, 39(3), 973-979. https://doi.org/10.13031/2013.27584

Zetzsche, J. B., \& Newman, J. S. (1966). Subirrigation with plastic pipe. Agric. Eng., 47(1), 74-75. 